Review

\title{
Advanced Breeding Strategies and Future Perspectives of Salinity Tolerance in Rice
}

\author{
Md Azadul Haque 1,2迆, Mohd Y. Rafii 1,3,*®D, Martini Mohammad Yusoff ${ }^{3}$, Nusaibah Syd Ali ${ }^{4}$, \\ Oladosu Yusuff ${ }^{1}{ }^{10}$, Debi Rani Datta ${ }^{1}$, Mohammad Anisuzzaman ${ }^{1,5}$ and Mohammad Ferdous Ikbal ${ }^{1,2}$ \\ 1 Institute of Tropical Agriculture and Food Security, Universiti Putra Malaysia, \\ Serdang 43400, Selangor, Malaysia; mahaquebina@gmail.com (M.A.H.); oladosuy@gmail.com (O.Y.); \\ debi.datta@yahoo.com (D.R.D.); anis.breeding94@gmail.com (M.A.); binaikbal@gmail.com (M.F.I.) \\ 2 Bangladesh Institute of Nuclear Agriculture, BAU Campus, Mymensingh 2202, Bangladesh \\ 3 Department of Crop Science, Faculty of Agriculture, Universiti Putra Malaysia, \\ Serdang 43400, Selangor, Malaysia; martinimy@upm.edu.my \\ 4 Department of Plant Protection, Faculty of Agriculture, Universiti Putra Malaysia, \\ Serdang 43400, Selangor, Malaysia; nusaibah@upm.edu.my \\ 5 Bangladesh Rice Research Institute, Joydevpur, Gajipur 1701, Bangladesh \\ * Correspondence: mrafii@upm.edu.my
}

Citation: Haque, M.A.; Rafii, M.Y.; Yusoff, M.M.; Ali, N.S.; Yusuff, O.; Datta, D.R.; Anisuzzaman, M.; Ikbal, M.F. Advanced Breeding Strategies and Future Perspectives of Salinity Tolerance in Rice. Agronomy 2021, 11, 1631. https://doi.org/10.3390/ agronomy11081631

Received: 29 June 2021

Accepted: 27 July 2021

Published: 17 August 2021

Publisher's Note: MDPI stays neutral with regard to jurisdictional claims in published maps and institutional affiliations.

Copyright: (c) 2021 by the authors. Licensee MDPI, Basel, Switzerland. This article is an open access article distributed under the terms and conditions of the Creative Commons Attribution (CC BY) license (https:// creativecommons.org/licenses/by/ $4.0 /)$.

\begin{abstract}
Rice, generally classified as a typical glycophyte, often faces abiotic stresses such as excessive drought, high salinity, prolonged submergence, cold, and temperature, which significantly affects growth, development, and ultimately, grain yield. Among these negative impacts of abiotic factors in rice production, salinity stress is a major constraint, followed by drought. There is considerable research on the use of marker-assisted selection (MAS), genome editing techniques, and transgenic studies that have profoundly improved the present-day rice breeders' toolboxes for developing salt-tolerant varieties. Salinity stresses significantly affect rice plants during seedling and reproductive stages. Hence, greater understanding and manipulation of genetic architecture in developing salt-tolerant rice varieties will significantly impact sustainable rice production. Rice plants' susceptibility or tolerance to high salinity has been reported to be the result of coordinated actions of multiple stress-responsive quantitative trait loci (QTLs)/genes. This paper reviews recent literature, updating the effects of salinity stress on rice plants and germplasm collections and screening for salinity tolerance by different breeding techniques. Mapping and identification of QTLs salt tolerance genes are illuminated. The present review updates recent breeding for improvement in rice tolerance to salinity stress and how state-of-the-art tools such as MAS or genetic engineering and genome editing techniques, including mutagenesis and conventional breeding techniques, can assist in transferring salt-tolerant QTLs genes into elite rice genotypes, accelerating breeding of salt-resistant rice cultivars.
\end{abstract}

Keywords: salinity stress; marker-assisted selection (MAS); genome editing techniques; transgenic; quantitative trait loci (QTLs); genes; rice

\section{Introduction}

Rice (Oryza sativa L.) is the most important staple food crop for more than 3.5 billion people worldwide, particularly in Asia and Africa. By the year 2050, the world's population is expected to reach 9.6 billion people [1]. Hence, there is an urgent need to enhance rice production to meet the rising global food demand. This target must be achieved in the face of rising biotic and abiotic stresses caused by climate change and further overwhelmed by growing competition for already scarce resources such as land and water. Conditions of drought, excessive salinity, cold, and heat are common causes of abiotic stresses that rice plants endure as growth proceeds in the ever-changing environment [2]. Numerous studies have cited that salinity stress is one of the most common abiotic stresses in rice, inhibiting 
crop growth, development, and ultimate yield production. It has been estimated that more than 1000 million hectares of land are saline or sodic, with records between $25 \%$ and $30 \%$ of irrigated areas (about 70 million hectares) being salt impacted and, in commercial terms, practically unproductive [3]. Previous studies have cited that soil salinity severely affected $50 \%$ of the world's population (around 4.03 billion people) in 13 countries. By the year 2050, seawater intrusion and inundation have been predicted to impact about 5.02 billion of the world population [4]. Rice is one of the most salt-susceptible cereal crops, characterized as having severely stunted plant growth and yield at a salinity level of $30 \mathrm{mmol} \mathrm{L}^{-1} \mathrm{NaCl}\left(3 \mathrm{dSm}^{-1}\right)$ [5]. Recent studies have indicated that rice is more salttolerant at germination and vegetative stages than seedling and reproductive stages due to a weak association between the latter two salt-susceptibility stages. Recent studies have also noted that rice plants have adopted several coping strategies with salinity stress at the various development stages. About $12 \%$ yield reduction was recorded in modern high yielding rice varieties above a salinity level of $3 \mathrm{dSm}^{-1}$. At a salinity level of $6 \mathrm{dSm}^{-1}$, about $50 \%$ yield reduction has been recorded [6].

Rice has a small genome size and wide genetic diversity. With the availability of whole-genome sequences and promising genome editing techniques, rice has been acknowledged as a model plant for genomic and molecular research [7]. In recent years, development in salt-tolerant varieties and studies on mechanisms of salinity tolerance have made essential contributions. Nonetheless, because of complications in plants' responses to salts stresses, which include intrinsic components of osmotic, ionic, and oxidative stresses, the development of salt-resistant rice varieties remains challenging [8]. It has been documented that coordinated actions of multiple stress-responsive quantitative trait loci (QTL) genes and metabolic pathways may determine salinity tolerance in rice. Although several genes/QTLs associated with salinity stress have been comprehensively mapped in rice, none have been incorporated into commercial cultivars [9,10]. Studies have extensively shown that salt stress inhibits growth and photosynthesis, resulting in reduced biomass and partial grain sterility, leading to decreases in rice production [11].

Several researchers have reviewed response mechanisms in salinity-stressed rice. However, only a few have focused on advances made in developing salt-resistant varieties. Consequently, the development of salinity-resistant rice varieties is regarded as the most promising and effective way to ensure food security. In this review, the effects of salinity stress on rice plants, rice germplasm collections and screening for salt tolerance, and fine mapping and identification of QTLs/genes for improving salt tolerance are discussed. The review is also complemented with different and recent advancements in breeding methods for improving and developing salt-tolerant rice varieties. Biotechnological approaches for salt tolerance are also reviewed, including the state-of-the-art tools such as markerassisted selection (MAS) or genetic engineering and genome editing techniques such as mutagenesis and conventional breeding, which may enhance introgression of QTLs/genes associated with salinity into elite rice genotypes in an attempt to accelerate breeding for salt-resistant cultivars.

\section{Effect Salinity Stress on Rice Growth, Development and Grain Yield}

Plant responses to salinity stresses are considered natural and random processes to increase rice grain yield under salt-stressed conditions. In the literature, salt tolerance is a complex quantitative trait governed by multiple gene interactions [12]. Rice crops are highly susceptible to salt stresses, particularly in the early growth stages [5] and in the reproductive stages [13], leading to significant grain yield reduction. Several studies have recorded that Indica rice is more salt-tolerant than japonica rice [14]. Morpho-physiological, biochemical, and molecular parameters have been reported to be affected by salinity stress. The effects of salinity stress on morpho-physiological parameters include inhibition in seed germination, stunting of growth of roots and shoots, reduction in tiller number per plant, number of grains per panicle, and pollen viability, with delays in seed setting and occurrence of sterile spikelets, decreased total dry matter accumulation, poor leaf area 
development, and crop area establishment (Figure 1) [15]. Several researchers have also reported the effects of salt stress on rice seedling establishment and seedling growth and reductions in yield and yield-related traits such as grain number per hill and effective tiller number per hill [16]. Salinity stress in rice has also been reported to induce biochemical and physiological changes, causing growth inhibition and consequential yield losses [17]. Evaluation of salinity-tolerant lines based on morpho-physiological parameters such as plant height, dry matter accumulation, leaf injury, and ratio of $\mathrm{Na}^{+} / \mathrm{K}^{+}$content in leaves and roots has been investigated to understand the drastic effects of the accumulation of salts at the physiological level [18]. Three main effects on rice plants have been reported and include lowering of water potential, impaired uptake of essential nutrients, and direct toxicity of sodium $\left(\mathrm{Na}^{+}\right)$and chlorine $\left(\mathrm{Cl}^{-}\right)$[19]. Uptake of sodium $\left(\mathrm{Na}^{+}\right)$, kalium $\left(\mathrm{K}^{+}\right)$, and calcium $\left(\mathrm{Ca}^{2+}\right)$ ions; total cation and osmotic stress; relative growth rate; and transcription efficiency are some of the physiological characteristics that are altered by salinity stress [20]. Studies have also cited that proline, anthocyanins, peroxidase activity, calcium, sodium, potassium, chlorophyll, and hydrogen peroxide concentrations are all biochemical characteristics of rice affected by salt-stress [21].

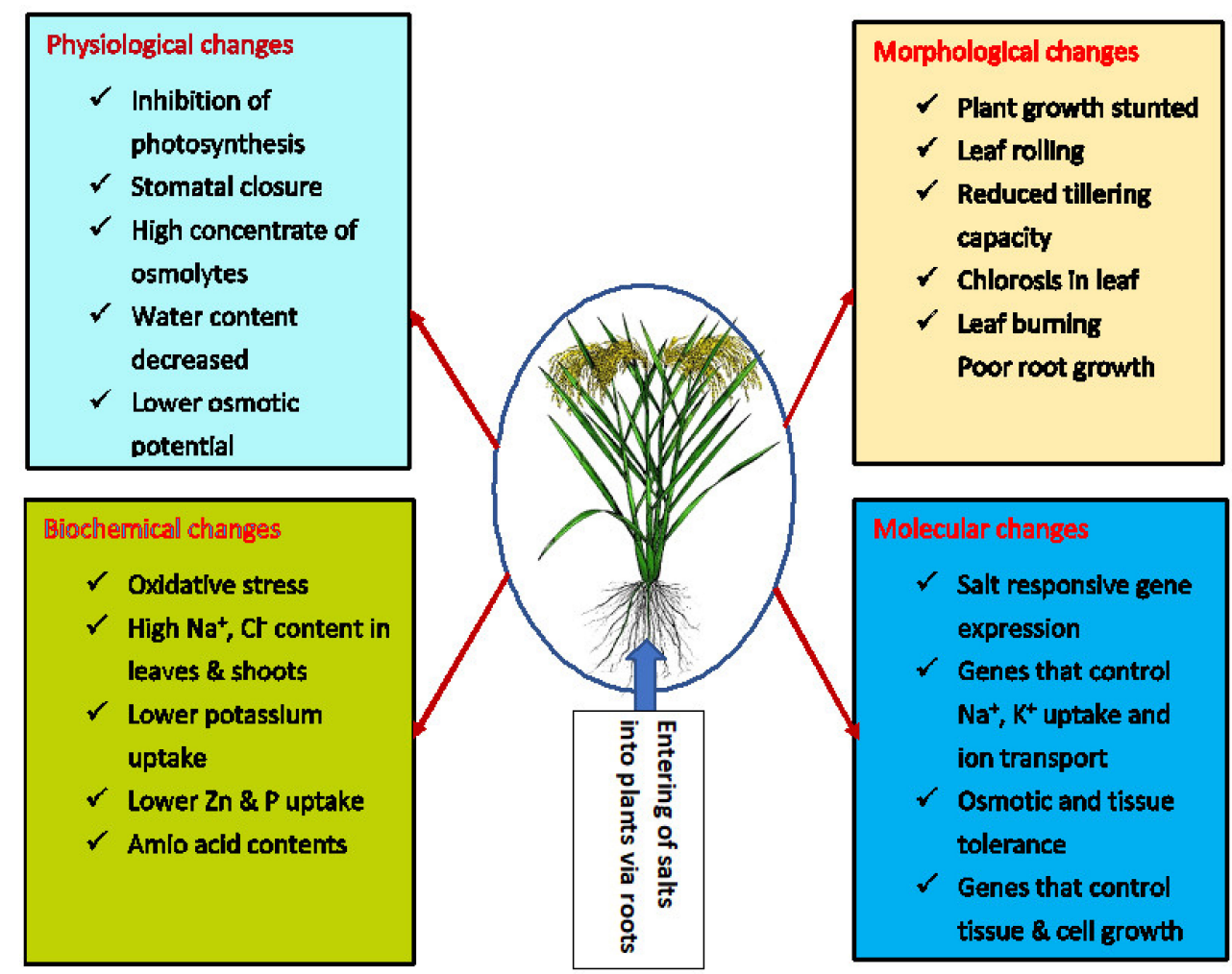

Figure 1. The effect of salt stress on rice physiological, biochemical, and molecular mechanisms.

The nutritional content of rice grains includes a range of minerals, including calcium, magnesium, and phosphorus, and trace elements such as iron, copper, zinc, and manganese. Vitamins including thiamine, riboflavin, and niacin are also found in rice and are also affected by salinity stress [22]. Several studies have demonstrated that salinity stress affects macro-and micronutrients elements absorption and uptake [23]. A study evaluated macronutrient and micronutrients contents in rice grains of Pokkali and KDML105 under saline circumstances and observed that salt stress caused substantial decreases in macronutrient components but increased $\mathrm{Ca}^{2+}$ content of both rice varieties. In another study, quantities of manganese, copper, and zinc were higher in Pokkali than in KDML105 [24]. Salinity has also been reported to increase sodium, iron, and zinc concentrations and decrease phosphorous and manganese. Nitrogen, magnesium, copper, potassium, and calcium contents were observed to be unaffected in the genotypes studied [24]. These 
investigations revealed that the impact of salinity stress on rice grain quality is complex and varied depending on salt concentrations and rice genotypes.

\section{Breeding Strategies to Improve Salt Tolerance in Rice}

\subsection{Mining and Screening of Salt-Tolerance in Rice Germplasm}

Rice has numerous natural genetic variations, within both species and genera. The International Rice Research Institute (IRRI) has preserved more than 130,000 rice accessions from different countries and regions worldwide. Some rice accessions are wild types or wild relatives or landraces, including cultivated species (https: / /www.irri.org/internationalrice-genebank, accessed on 30 December 2019). As has been previously reported in the literature, wild rice relatives can improve cultivated rice's salt tolerance, and integrating QTLs/genes resistant to salt-stress characteristics from wild species into cultivated rice is seen as a viable strategy to increasing rice's salinity tolerance [25]. Under various salinity treatments, thousands of rice genotypes have been screened at the seedling stage using different parameters [26]. Germination index, germination percentage [27], plant survival, salt injury score and dry matter indicator at the vegetative stage [28], water use efficiency and chlorophyll content [29], relative growth rate, and concentrations of $\mathrm{Na}^{+}$and $\mathrm{K}^{+}$in shoots and roots [30] were among the indicators observed.

A previous study revealed a wide range of genetic variabilities between rice accessions O. sativa and O. glaberrima in salinity tolerance [31]. Indian accessions O. rufipogon and $O$. nivara were reported to have moderate tolerance to salinity [32]. Salt screenings were reported to have been applied at various salt levels and short periods (10-14) at seedling stages, focusing on osmoprotectants in plants for salt stress [33], when ion toxicity was not present. A recent study was conducted on two landraces adapted to seawater, namely Changmaogu [34] and Sea Rice 86 [35], both discovered in the coastal region of China. At the germination stage, the salt-tolerant rice variety Pokkali showed lower tolerance to salinity than Changaogu, with $18.7 \%$ germination in $140 \mathrm{mmol} \mathrm{L}^{-1}(\sim 0.8 \%) \mathrm{NaCl}$ treatment [34]. A recent study reported that, at $0.8 \% \mathrm{NaCl}$ salinity treatments, $98 \%$ germination was recorded by Sea Rice 86, with no germination recorded above this level [35]. Salinity tolerance existed among wild rice, but the tolerance level was reported to have been lost [25]. Recently, Oryza coarctata species appeared more promising towards salinity tolerance with KKLL gene [36]. Understanding the molecular and physiological mechanisms underlying its enhanced salt tolerance might pave the way for certain essential features to be included in breeding programs [37]. For example, in an allele mining program, L-myo-inositol 1-phosphate synthase (MIPS) protein was reported to increase salinity tolerance in rice, which was a unique example of molecular salinity tolerance [38]. In addition to natural diversity, various mutants for salt tolerance in rice have been found. After screening $>270,000$ ethyl methanesulfonate (EMS)-mutagenized $\mathrm{M}_{2}$ rice seedlings of Zhonghua 11 at $140 \mathrm{mmolL}^{-1} \mathrm{NaCl}$, the dst mutant was discovered. Drought and salt tolerance (DST) is a crucial gene that encodes a zinc finger transcription factor that regulates stomatal aperture by directly manipulating the modulation of genes related to $\mathrm{H}_{2} \mathrm{O}_{2}$ homeostasis in guard cells. It was found to be a negative regulator of drought and salt tolerance in rice [39]. From 6000 EMS mutant lines of the local elite cultivar, Hitomebore, a salt-tolerant mutant with hitomebore salt-tolerant 1 gene (hst1), was chosen. The loss-of-function of OsRR22, a cytokinin signaling protein, was discovered to be the cause of the salinity-tolerance trait of $h s t 1$ [40].

\subsection{QTLs/Genes Mapping to Improve Salt-Tolerant Rice}

Soil salinity tolerance is a complex physiological trait and is genetically controlled by QTLs [41]. Many QTLs have been identified and linked to salinity resistance in rice (Table 1). Presently, only a few significant QTL mappings or isolations were successfully done by genomic methods. Two major QTLs, $q S N T Q-7$ and $q S K C-1$, from crossing between salt-susceptible Koshihikari and salt-tolerant Nona Bokhra, were identified for $\mathrm{Na}^{+}$and $\mathrm{K}^{+}$ concentrations in shoots [42], as $q S N T Q-7$ and $q S K C-1$ QTLs regulate $\mathrm{K}^{+} / \mathrm{Na}^{+}$homeosta- 
sis under saline conditions. The qSNTQ-7 and qSKC-1 QTLs recorded 48.5 and $40.1 \%$ of total phenotypic variation, respectively [42]. The $q S K C-1$ gene includes a member of the HKT-type transport family isolated by map-based cloning [18]. The Saltol QTLs on chromosome 1 controls $\mathrm{Na}^{+} / \mathrm{K}^{+}$homeostasis in the Pokkali cultivar resistant to salinity, mapped from crossing Pokkali and IR29 [43]. The qSE3 QTLs represent OsHAK21, a potassium transporter gene that influences rice seedling establishment and seed germination under salt stress [44]. The qST1 and qST3 QTLs are identified on chromosome 1 and 3, which confer salinity tolerance at the seedling stage and $36.9 \%$ phenotypic variations recorded in the recombinant inbred line (RIL) population [45]. The qST1 QTLs plays a vital role in salinity tolerance and recorded $62.6 \%$ phenotypic variations in Sea Rice (SR86) [46]. Mapping, cloning, and identification of the gQTLs in rice are the steps forward for associating salinity resistance. In light of reported studies on salinity tolerance, it is conceivable that further research should focus on discovering the major salinity resistance genes and their salt responsive mechanisms in rice. Focus should be on the markers that assist the incorporation/introgression of these QTLs into elite rice varieties through marker-assisted backcrossing (MABC) to develop salt-resistant rice varieties.

Considerable progress has been made through genetic dissection and molecular analyses in responses to salt stress to identify and map the genes involved in salinity stress in rice (Table 2). It is noted that researchers are more interested in identifying the salttolerant genes associated with reactive oxygen species (ROS) metabolism, as maintaining a proper level of ROS is essential for plant survival under salt stress conditions. The level of ROS in rice plants depends on ROS biosynthesis and ROS scavenging traits. Salinity induces the expression of respiratory burst of oxidase homologus (Rbohs), which catalyzes the conversion of $\mathrm{O}^{2}$ to $\mathrm{O}^{2-}$ [47]. Rbohs are candidate genes that improve salinity tolerance. Genes associated with ROS biosynthesis and ROS scavenging improve salinity tolerance in rice. For instance, ascorbate peroxidase (APX) converts $\mathrm{H}_{2} \mathrm{O}_{2}$ and $\mathrm{O}_{2}$, where APX enzyme acts as a specific electron donor [48]. Overexpression of other antioxidative genes such as OsECS, OsVTE1, and OsMSRA4.1 in transgenic rice had shown high salt tolerance [49]. The overexpression of APX genes enhances salinity tolerance by reducing ROS in plants. The knockdown of OsVTC1-1 and OsVTC1-3 genes enhances salinity tolerance by synthesizing ascorbate enzyme and increasing ROS level accumulation in plants [50]. Genes associated with $\mathrm{Na}^{+} / \mathrm{K}^{+}$homeostasis are also candidate genes for increasing salinity tolerance in rice. The changing ratio of $\mathrm{Na}^{+} / \mathrm{K}^{+}$in rice plants leads to metabolic changes. $\mathrm{Na}^{+}$ion inhibits the growth and development of rice plants through $\mathrm{Na}^{+}$toxicity. $\mathrm{K}^{+}$ion promotes the growth and development of rice plants. Therefore, the prohibition of intercellular accumulation of $\mathrm{Na}^{+}$toxic ions is essential for rice plants' survival under salinity resistance. High-affinity $\mathrm{K}^{+}$transporter (HKT) family genes are $\mathrm{Na}^{+}, \mathrm{Na}^{+} / \mathrm{K}^{+}$transporters.

In rice, HKT genes also restrict the accumulation of toxic $\mathrm{Na}^{+}$ions in roots and ultimately change intercellular $\mathrm{Na}^{+}$accumulation content and increase salt tolerance [51]. This suggests that modification of the ion channel is an option to develop rice variety resistance to salt stress. Genes associated with $\mathrm{Na}^{+} / \mathrm{K}^{+}$homeostasis and ROS also significantly regulate salinity resistance [52], such as overexpression of OsEXPA7, a cell wall-loosening protein gene increasing salinity tolerance by coordinating sodium transport, cell-wall loosening, and ROS scavenging [53]. The OsRR22, a response regulatory protein, acts as a transcription factor (TF) that regulates genes associated with osmotic stress or ion transport in the roots [40]. The OsCYP71D8L negatively regulates salinity resistance and affects cytokinin and gibberellin homeostasis [54]. A ubiquitin-binding protein acts as a dominant suppressor of KAR2 (OsDSK2a), enhancing rice seedling growth and salinity responses [55]. Many salt tolerance genes have been successfully identified, mapped, and cloned. Overexpression of these genes has also been carried out. The focus is now on the introgression of those genes for developing salt-tolerant rice varieties using marker aided selection breeding methods. 
Table 1. List of QTLs mapped and identified in rice for salinity tolerance.

\begin{tabular}{|c|c|c|c|c|}
\hline Parents & Number of QTLs & Functions & Stage & Reference \\
\hline Dianjingyou $\times$ See Rice 86 & 1 & Enhances salinity tolerance at the seedling stage & Seedling & [46] \\
\hline Ahlemi Tarom $\times$ Neda & 73 & Enhances salinity tolerance in rice at seedling Stage & Seedling & [56] \\
\hline Nona Bokra $\times$ Koshihikari & 2 & $\begin{array}{c}q S N C-7 \text { for shoot } \mathrm{Na}^{+} \text {concentration and } q S K C-1 \text { for shoot } \mathrm{K}^{+} \\
\text {concentration, explained } 48.5 \% \text { and } 40.1 \% \text { of the total phenotypic } \\
\text { variance, respectively }\end{array}$ & Seedling & [58] \\
\hline BRRI dhan $29 \times$ Capsule & 16 & Salinity tolerance at the seedling stage & Seedling & [59] \\
\hline Sahel $317 \times$ Madina Koyo & 13 & Resistance to salinity at the early seedling stage & Early seedling & {$[60]$} \\
\hline $\mathrm{LYP}_{9} \times \mathrm{PA} 64 \mathrm{~s}$ & 38 & Seedling stage & Seedling & [61] \\
\hline Gharib $\times$ Sepidroud & 41 & Growth of rice at the seedling stage under high salinity & Seedling & [62] \\
\hline IR29 $\times$ Pokkali & 23 & Long-distant $\mathrm{Na}^{+}$transport from roots to shoots in rice & Seedlings & [63] \\
\hline Jiucaiqing $\times$ IR26 & 16 & $\begin{array}{c}\text { Controlling rice seed germination under salt stress at seed } \\
\text { germination stage }\end{array}$ & Germination & [64] \\
\hline Cheniere $\times$ Nona Bokra & 32 & Enhanced salt tolerance at seedling stage & Seedling & [65] \\
\hline Pokkali $\times$ Bengal & 50 & Seedling salinity tolerance & & [67] \\
\hline Ilpumbyeo $\times$ Moroberekan & 8 & Seedling stage & Seedling & [68] \\
\hline Yiai $1 \times$ Lishuinuo & 13 & Salt or alkaline tolerance at the seedling stage in rice & Seedling & [69] \\
\hline Tarommahali $\times$ Khazar & 3 & Salt tolerance in young rice seedlings & Young seedling & [70] \\
\hline Sadri $\times$ FL478 & 35 & Yield and yield components under reproductive stage salinity stress & Reproductive & [71] \\
\hline CSR27 $\times$ MI48 & 25 & $\mathrm{Na}^{+}, \mathrm{K}^{+}$, and $\mathrm{CI}^{-}$ion concentrations in salt-tolerant indica rice & Seedling & [72] \\
\hline IR29 $\times$ Hasawi & 34 & Enhances salinity resistance & Seedling & [73] \\
\hline OM7347 × OM5629 & 9 & Enhances salinity tolerance & $\begin{array}{l}\text { Seedling, vegetative and } \\
\text { reproductive }\end{array}$ & [74] \\
\hline Kalarata $\times$ Azucena & 13 & Associated with salinity stress & Seedling & [75] \\
\hline Wujiaozhan $\times$ Nipponbare & 13 & Confers seed germination traits under $\mathrm{H}_{2} \mathrm{O}$ and salt conditions & Germination & [76] \\
\hline Horkuch $\times$ IR29 & 14 & Enhances salinity tolerance & Seedling and reproductive & [77] \\
\hline
\end{tabular}


Table 2. List of salinity tolerance genes and their functions for breeding of salt-tolerant rice.

\begin{tabular}{|c|c|c|c|}
\hline Target Genes & Gene Function & Expression & Reference \\
\hline OsTPS1 & Enhances salinity, drought, and cold tolerance in transgenic rice & Overexpression & {$[18,78]$} \\
\hline OsSPL10 & SBP-box gene, negatively controls salt tolerance but positively controls trichome formation in rice & Overexpression & [79] \\
\hline OsEXPA7 & Improves salt stress tolerance in rice by regulating ion homeostasis, ROS scavenging, and cell wall-loosening & Overexpression & [53] \\
\hline OsMYB6 & MYB family gene, increases drought and salinity stress tolerance in transgenic rice & Overexpression & [80] \\
\hline OsMADS25 & $\begin{array}{c}\text { Transcriptional regulator that regulates the root growth and confers salinity tolerance in rice via the ABA-mediated } \\
\text { regulatory pathway and ROS scavenging }\end{array}$ & Overexpression & [81] \\
\hline OsSOS1 & Regulate ion transport regulation under salt stress & Overexpression & [82] \\
\hline OsDOF15 & Contributes to ethylene-inhibited primary root elongation under salt stress & Overexpression & [83] \\
\hline OsGA2ox5 & A gibberellin metabolism enzyme, GAs homeostasis, development, gravity responses, and stress tolerance in rice & Ectopic expression & [84] \\
\hline OsCDPK7 & Positive regulator involved in both cold and salt/drought tolerance in rice & Overexpression & [85] \\
\hline OsCPK21 & A calcium-dependent protein kinase, confers salinity tolerance in rice & Overexpression & [86] \\
\hline OsCPK12 & Calcium-dependent protein kinase, negatively regulate salt-stress tolerance & Overexpression & [87] \\
\hline OsCam1-1 & ABA biosynthesis and salt tolerance in rice & Overexpression & [88] \\
\hline OsRPK1 & Receptor-like protein kinase genes, negatively regulate salt tolerance & Overexpression & [90] \\
\hline
\end{tabular}




\subsection{Genome-Wide Association Study (GWAS) Technique}

The genome-wide association study (GWAS) is a powerful approach in understanding the genetic basis of complex traits and identified allelic variations of candidate genes in rice [91]. GWAS analyzed the statistical association between traits and genetic variants on the whole genome sequence and has been applied to identify causal genetic variability for targets traits [92]. GWAS enables high-resolution mapping, utilizing single nucleotide polymorphisms (SNPs) as genetic markers instead of the QTL linkage mapping approach [93]. In the indica subspecies of rice, GWAS has been conducted for agronomic characteristics such as tiller number, grain width, grain length, and spikelet number using single nucleotide polymorphisms (SNPs) discovered by whole-genome sequencing [94]. GWAS has been applied for mapping traits associated with loci responsible for salinity tolerance. A previous study reported that a total of 23 marker-trait associations (MTAs) were mapped for salinity tolerance at the early vegetative stage using GWAS. These MTAs were found on rice chromosomes 1, 2, 5, 6, 7, 9, and 12 and observed 13.98 to 29.88 percent of the trait phenotypic variations [95]. There are numerous GWAS applications under saline conditions in rice, with distinct growth phases and characteristics. Another study reported using 6000,000 SNPs to conduct a GWAS on the germination stage of salt-treated rice and recorded that 11 loci, including 22 significant SNPs, were responsible for stresssusceptibility indicators such as vigor index and germination time [27]. In another recent GWAS study, 27 QTLs for moderate salinity-related characteristics were mapped on 12 rice chromosomes. GWAS also studied 20 QTLs for 11 salt-resistant traits in rice at the germination and seedling stages [96]. GWAS identified two genes related to auxin biosynthesis as potential genes for salinity resistance from a large sample of 478 rice accessions [97]. Under salt stress conditions, 15 potential genes, transcription factors (TFs), and cation transporters were recently discovered to be connected with grain production and associated characteristics [98]. Several potential genes, including two SUMO proteases (OsSUMO1 and OsSUMO2) and a $\mathrm{K}^{+}$transporter gene (OsHAK6) have been associated with salinity tolerance in rice [99]. These identified material transfer agreements (MTAs), QTLs, and genes pave the path for molecular breeding to combine salinity tolerance with high yield characteristics in rice. In GWAS, the candidate genes Os09g0278000, Os09g0279100, Os09g0279400, Os09g0279500, and Os09g0280300 at locus 167 control early seedling vigor (ESV), conferring salinity tolerance in rice [26].

\section{Breeding Approaches for Developing Salt-Tolerant Rice \\ 4.1. Conventional/Traditional Breeding}

Genome and whole-genome sequences have contributed to the genomic study, proteomics, transcriptomics, metabolomics, and QTLs/gene mapping to improve salinity tolerance in rice. The collection of germplasms, including wild species, has provided important genetic diversity for salinity tolerance, and the success of a breeding method depends largely on the choice of germplasms. Screening rice germplasms to identify salt tolerance genotypes has led to the development of salt-tolerant rice by transferring genes. Genetic diversity analyses of 107 rice accessions were conducted using 376 single nucleotide polymorphism (SNP) markers to characterize the allelic variations on a major QTL, Saltol. The results indicated that rice landraces, e.g., Akundi, Ashfal, Capsule, Chikirampatnai, Jatai Balam, Kalarata, and Kutipatnai, tolerated salinity through the accumulation of more $\mathrm{K}^{+}$ion with less $\mathrm{Na}^{+}$ion, and lower levels of $\mathrm{Na}^{+} / \mathrm{K}^{+}$ratio in leaves [100]. These landraces provide valuable resources for developing salinity-tolerant rice and other abiotic stresses.

Conventional breeding methods such as hybridization, recurrent selection, pedigree selection, backcrossing, and induced mutations have been applied to develop salt-tolerant rice. Several researchers have developed salt-tolerant rice varieties by conventional breeding methods [101]. Since the 1970s, the International Rice Research Institute (IRRI) has developed more than 30 salinity-resistant varieties using sexual hybridization approaches. Varietal development through traditional/conventional breeding requires six to seven years or more. The rice varieties developed through traditional breeding methods contain 
unwanted deoxyribonucleic acid (DNA) from donor parents. Such a variety fails to achieve a well-known exclusive cultivar. Conventional breeding methods are slower, more timeconsuming, inefficient, unreliable, and laborious [99]. Success in conventional breeding depends on the proper mapping/identification of genes for new varietal development process. Wild species and landraces are the prime considerations for the success of conventional breeding due to their greater genetic variations in response to salinity [102]. Salinity resistance varietal development relies on identifying QTLs/genes linked to target genes and tightly linked molecular markers applied in marker-assisted selection (MAS) [103].

\subsection{Marker-Assisted Selection}

The use of molecular markers linked to agronomic traits of interest controlled by individual genes or QTL is called MAS [104]. This is the most promising and successful method for developing new salt-tolerant rice lines [105]. The use of MAS can shorten the breeding cycle by allowing for the selection of plants with the target genes at the early growth stages saving labour, time and agricultural inputs such as fertilizer, pesticides and irrigation and is not influenced by environmental factors. Marker-assisted backcross (MABC) breeding is faster and more precise to introgress/transfer linked genes for salinity tolerance. MABC allows selecting plants in each breeding season to confirm the introgressed target genes and recovery of parental genome (RPG) and reduced linkage drag [106]. The recovery of parental genome of developed lines can be estimated. The distinctness, uniformity, and stability (DUS) test of developed rice lines confirms the percentage of RPG of parental traits with SNP marker genotype [107]. A variety of molecular markers are available to identify various QTLs and introgression of QTLs into elite rice genotype through MAS. SNPs simple sequence length polymorphisms (SSLPs), restriction fragment length polymorphisms (RFLP), amplified fragment length polymorphisms (RFLP), sequence-tagged sites (STS), and simple sequence repeats (SSRs), or microsatellites, are all DNA markers used for genotyping in molecular mapping studies and MAS [108]. Utilizing the SSR marker, the QTLs of pollen fertility; $\mathrm{Na}^{+}$concentration; and calcium $\left(\mathrm{Ca}^{2+}\right)$, sodium $\left(\mathrm{Na}^{+}\right)$, and potassium $\left(\mathrm{k}^{+}\right)$ accumulation in the $F_{2}$ rice populations have been reported [109]. QTLs for yield and yield contributing characteristics and physical traits were recorded using $\mathrm{F}_{2}$ rice populations as plant materials and SSRs as a DNA marker [109]. QTLs for potassium and sodium absorption for improving salt tolerance in rice have been determined using AFLP, RFLP, and SSR [110]. SNP has been used to identify the QTLs of salt stress-sensitive genes in rice [111]. SSRs markers linked to Saltol QTL include RM3412, AP3206, RM10796, RM8094, RM493, RM10793, some functional markers, and SNP [112]. RAPD markers have been developed, identified, and applied into marker-assisted selection breeding programs [113]. The availability of molecular marker development for MAS is still in progress. MAS utilizes novel sources of genetic materials provided by allelic variations in the gene of interest and can create, design, and develop a cheap molecular marker for salt tolerance [114]. By applying MABC, Saltol QTLs was introgressed into a popular elite variety in different countries: Saltol QTLs was introgressed into two Bangladeshi varieties, BR11 and BRRI dhan28 [115], AS996 and BT7 in Vietnam [116], Rassi in West Africa [117], and Pusa Basmati 1121 and PB6 in India [103,118]. In India, a multi-institutional program on the introgression of Saltol QTLs into elite mega-rice varieties is in progress [106,119]. Marker-assisted gene/QTLs pyramiding has been proven to be a powerful tool to introgress multiple genes/QTLs for broad-spectrum resistance to abiotic and biotic stresses [120]. Studies pyramiding multiple QTLs/genes in rice for tolerance to drought have been carried out [121], as have studies investigating salinity and submergence tolerance through MAS [122] by pyramiding genes for disease resistance, submergence tolerance, and aromatic fragrance [123]. Additionally, genes have been pyramided for bacterial leaf blight under deep water rice through MAS. Presently, marker-assisted gene pyramiding for developing salinity tolerance rice variety using MAS has been proven to be a promising technique. 


\subsection{Transgenic Approach}

Genetic engineering has become a powerful technique in modern plant breeding. It allows the introduction of the gene of interest into elite cultivars without compensating for desirable characteristics. The introduction of an effective agrobacterium-mediated transformation technique has contributed significantly to genetic improvement in rice [124]. Generally, salinity tolerance through genetic modification focused on genes that encode late embryogenesis abundant and heat-shock proteins, transcription and signal transduction factor, programmed cell death, detoxification of ROS (antioxidants), compatible organic solutes, and ion transport [124]. In addition, all identified techniques used by rice plants in coping with salinity have been utilized in genetic modification to develop rice salinity tolerance. The expression of salt-responsive genes such as phosphatase 1a (OsPP1a) contributes to salinity tolerance in rice. The $n R K 1 A$, OsNAC5, and OsNAC6 genes are also upregulating in transgenic lines, viz, OsPP1a-2, OsPP1a-3, and OsPP1a-6 [125]. Transgenic rice demonstrates salinity tolerance through the accumulation of $\mathrm{Na}^{+} / \mathrm{H}^{+}$in both shoots and roots under salinity treatments. Sodium proton antiporter is one of the potential gene families in rice showing multiple stress responses under abiotic stress conditions. $\mathrm{OsNHX}_{1}$ genes were derived from landraces Pokkali, a vascular $\mathrm{Na}^{+} / \mathrm{H}^{+}$antiporter gene overexpression that enhances the level of salinity tolerance in transgenic rice [126]. The accumulations of $\mathrm{Na}^{+} / \mathrm{H}^{+}$in shoots and roots changed biomass production and germination, which also improved by overexpression of OsNHX1 genes [127]. The overexpression of treholose-6-phosphate synthase, associated with OsTPS1 genes, was reported to enhance salinity, drought, and cold tolerance in transgenic rice. It also increases the accumulation of compatible solutes by reducing wilting and maintaining photosynthetic activities in transgenic rice [78]. Ectopic expression of the $P t C Y P_{714} A_{3}$ gene in transgenic rice promotes active tillering, with reduced seed size and semi-dwarfed phenotypes. These findings provide the essential roles of molecular foundation in transgenic research in rice responses to salinity and the roles of $P t C Y P_{714} A_{3}$ in shoot responses to salinity [128]. Li et al. reported that the overexpression of SIDP361 genes enhances salinity tolerance in rice at the seedling and reproductive stages. The genes have high potential as a tool for genetic engineering for salt-tolerant rice [129]. Previous studies on OsSUV3 overexpression in transgenic rice increased the concentrations of gibberellic acid $\left(\mathrm{GA}_{3}\right)$, zeatin $(\mathrm{Z})$, and indole-3-acetic acid (IAA) in leaves, stems, and roots as compared to wild-types, with reduced adverse effects of salinity on the growth and development of rice plants [130]. Pea DNA helicase $45\left(\mathrm{PDH}_{45}\right)$ genes in transgenic rice accumulate lower concentrations of $\mathrm{Na}^{+}$, ROS, and calcium homeostasis in roots under salinity stress by maintaining cell viability [131]. High-salt induction of OsPP1a in transgenic plants upregulate the expression of SOD significantly [125]. Salinity tolerance transgenic rice was developed through over-expression of the OsIF genes from wild rice (Porteresia coarctata) native to Bangladesh, India, and Myanmar.

The bulk of transgenic rice is developed in the United States (11.5 percent), Europe $(8.9 \%)$, Oceania (1.1 percent), and Africa (1\%), while the majority of field trials have taken place in Asian countries (77.5\%), primarily in China (47.8\%) and Japan (1\%). Developing countries such as Bangladesh, Myanmar, Thailand, Nepal, and Bhutan are still developing transgenic rice due to lack of modern laboratory facilities and technical knowledge. Salinity tolerance in rice is physiologically and genetically complex due to some critical aspects, e.g., ion homeostasis and compartmentation, programmed cell death, signal transduction, and transcription factors that are regulated by respective sets of genes. No single cultivar has been released to farmers for commercial cultivation despite the number of salinity tolerance rice cultivars developed through the transgenics approach. The extension of this rice variety is still the prime obstacle due to complicated procedures for transgenic rice. Genetically modified rice must adhere to the worldwide Cartagena Protocol, which is applied in each country by its own biosafety rules [132]. The primary hindrances to the extension of transgenic rice are asynchronous approval and release processes, propagation of illegal seeds, and contamination in non-labelled transgenic rice producers in countries with zero tolerance [133]. Therefore, the primary obstacles to implementing a transgenic 
method include limited public acceptability in different countries, prior knowledge of gene sequences, necessary laboratory infrastructures, and strict rules and regulations.

\subsection{Mutation Breeding}

In recent years, huge progress in functional genomics research among cereal crops has been recorded [134]. Mutation breeding can be applied as a vital tool for creating genetic variability in rice crops and functional gene study [135]. Mutagenesis is an important technique for increasing the frequency of mutants, which can help in functional genomic research and lead to the development of new genotypes [136]. Mutation occurs through the application of biological, chemical, or physical mutagens [137]. In rice, the level of dose and exposure time regulate the degree of mutations [138]. Mutagenesis in rice is advantageous because of its small genome, which requires a smaller population to saturate the entire genome and provide a wider allelic series sequence [139]. Several rice mutants have been developed in different countries using random mutations such as Amaroo rice mutant variety in Australia [140]; Binasail, Iratom-24, and Binadhan-6 rice mutants in Bangladesh; 26 Zhaizao and Zhefu 802 rice mutants in China [141]; PNR-381 rice mutants in India [141]; Basmati 370 rice mutant in Pakistan [141]; Calrose 76 rice in the United States [142]; and VND 95-20, VND-99-1, and VN121 rice mutants in Vietnam. While efforts to increase salt stress resistance by genetic changes have achieved significant results, the mutation technique is a primary strategy for obtaining salt-tolerant varieties and other desirable characteristics [143]. Mutation breeding has an important role in improving high yield and rice resilience to salt stress [144]. There are several successful applications of mutation breeding to increase salt tolerance. For instance, carbon $(\mathrm{C})$ and neon $(\mathrm{Ne})$ irradiated rice seeds have developed a mutant type with excellent salt tolerance [145]. The IAEA (2003) has reported the identification of eight salt-tolerant mutants with higher salinity tolerance than the parents. Six mutants have been produced from parent Bicol and two from salt sensitive parent IR29 [146]. Lee at al. [14] has developed salt-tolerant and sensitive mutants by applying gamma irradiation in the callus of a Korean rice variety, Dongjinbyeo. Salt-tolerant mutants have also been developed through in vitro anther cultures and double haploids by Sathish [147]. Lin et al. [148] developed a salt hypersensitive 1 (shs1) mutant using sodium azide, which plays a vital role in $\mathrm{Na}^{+}$homeostasis and antioxidant metabolism. Azolla varieties resistant to high salinity, hazardous aluminium levels, and pesticides were developed via mutation breeding [149]. Two mutant lines, ST-87 and ST-301, were developed using gamma-rays for salinity tolerance in rice by Song et al. [150]. Several salt-tolerant rice varieties, such as A-20, Shua92, Basmati370, Changwei19, Atomita2, Nipponbare, Fuxuan No. 1, Mohan-CSR4, Emai No. 9, and Changwei 19, have been developed by applying gamma rays and released in many countries all over the world [151]. By application of target mutations in rice, several genes have been modified for salinity tolerance via CRISPR/Cas9 and other genome editing approaches [152]. However, the application of mutagenesis breeding is restricted due to the randomness of mutation and problems with the regeneration of entire plants [153]. In addition, the high population size needed to screen phenotypes, occurrence of accidents, availability of mutagens, and specific infrastructures are all obstacles to the application of mutations.

\subsection{Genome Editing Techniques}

Genome modification through targeted genome editing has revolutionized plant genomics for improving plants' characteristics against biotic and abiotic stressors [154]. Mega nucleases, transcription activator-like effector nucleases (TALENs), zinc finger nucleases (ZFNs), and clustered regularly interspaced short palindromic repeats (CRISPR/Cas) systems have all been used to alter genomes [134]. CRISPR-Cas9 has been widely utilized to transform plants by inducing mutations via either homology-dependent repair (HDR) or non-homologous end-joining of double-stranded breaks (NHEJ) [155]. Previous studies revealed that CRISPR-Cas9 best targets specificity because the Watson and Crick model recognizes target sites, and sequence analyses identify off-target regions [156]. 
CRISPR/Cas9 splits foreign DNA via two components, Cas9 and a single guide RNA. The guide RNA consists of the CRISPR-derived RNA (crRNA) and trans-activating RNA (tracrRNA) systems. Cas9 is a DNA endonuclease obtained from several bacteria, including Brevibacillus laterosporus, Staphylococcus aureus, Streptococcus pyogenes, and S. thermophilus, with S. pyogenes [157] being the most commonly utilized for Cas9 isolations. Two domains are included in Cas9, the HNH domain and the domain RucV-like. The HNH breaks off the CRISPR RNA complementary strand (crNA), while RucV cuts off the opposite strand to the double-stranded DNA. The sgRNA is a synthetic RNA, approximately $100 \mathrm{nt}$ in length. The $5^{\prime}$-end sequence has a 20-nt sequence acting as the guide to identify the target sequence, which is frequently the NGG consensus, along with the PAM sequence ( $\mathrm{N}$, any nucleotide; $\mathrm{G}$, guanine). At the end $3^{\prime}$ of the sgRNA, the loop structure can attach the target sequence by means of the sequence guide and creates a Cas9 complex, which splits the double-stranded DNA and causes a double-strand break (DSB). When a DSB is created, DNA repair processes commences, either nonhomologous end-joining (NHEJ) or homology-directed repair (HDR). In most cases, the DSB is generally repaired by NHEJ and it is an easy way to produce malfunctions and deletions (indeles), resulting in knock-out. HDR causes certain replacement of gene or foreign DNA knock-ins when oligo template is available [158].

Since 2016, the sophisticated genome editing method utilized for plant gene editing has been the clustered regular interspaced short palindrome repeats of Prevotella and Francisella 1 (CRISPR/CPf1) [159]. This makes the CRISPR/Cpf1 system the most advanced and efficient genome editing technology, with several major benefits over the CRISPR/Cas9 system. Cpf1-crRNA complex can itself efficiently cleave the target DNA without needing tracrRNA I the CRISPR/Cpf1 system. For example, a 40-45 nt crRNA with repetition and spacer is sufficient to assist gene editing compared to the $100 \mathrm{nt}$ sgRNA employed in the CRISPR/Cas9 system [160]. Presently, three CRISPR/Cpf1 systems, FnCpf1, LbCpf1, and AsCpf1, are available for genome editing applications in rice [161].

Although CRISPR/Cas9 and CRISPR/Cpf1 based gene editing can be a convenient method for gene replacement, template DNA transport and targeted insert or gene replacement are relatively low in frequency and efficiency. A CRISPR/Cas9 based base editor technique is the latest and most sophisticated method that can be applied as an alternative method, which permits a direct and irreversible conversion of one target base into another without the need for a DSB or donor template [162]. The base editor merges the dormant Cas9 domain with a cytosine deaminase domain, which changes the base G-C pairings to A-T base pairs [163]. Base editing methods in grain crops such as rice, wheat, and maize have been optimized and have been shown to be effective [164]. A base editing construct known as nCas9-PBE, consisting of rat Cytidine deaminase APOBEC1 and a Cas9 variant Cas9-D10A nickase (nCas9), has been applied for editing the OsCDC48 gene in rice for cell death and senescence [165]. The results showed that rice editing of site-specific $C$ to $T$ base might be utilized efficiently with nCas9-PBE. Subsequently, the use of nCas9 coupled with a cytidine deaminase enzyme revealed a targeted point mutation in rice [166].

Due to its simplicity, flexibility, and great accuracy, CRISPR/Cas9 technology has been utilized effectively in key crops and model plants [167]. In rice, genome editing may be combined with innovation to create new varieties with greater yield and quality and a high resistance to abiotic and biotic stressors. CRISPR/Caa s9 has been widely utilized in several crops, including rice, where it has shown great promise in producing desired alterations in response to biotic and abiotic stressors [168]. There are several successful applications of CRISPR-Cas9 gene editing techniques in rice, viz, editing of transcriptomic factor MYB family genes, OsMYB1-OsMYB5, editing of the OsSPP gene for early seedling leaf chlorosis, the pleotropic phenotype controlling gene, OsMSH1, and the photoperiod sensitive male sterility responsive gene, OsPMS3, and also the drought resistance controlling gene, OsDERF1 [169]. Recently, [168] has developed rice lines for abiotic stresses by applying the CRISPR-Cas9 gene editing techniques, such as editing a transcription factor gene (TIFY1b) using rice variety Nipponbare. Improved blast resistance 
rice using Kuiku131 has also been developed by editing the OsERF922 gene, and herbicide resistance rice by editing the acetolactate synthase 1 gene (ALS1) [170]. The TMS5 [171], OsHAK1 [172], and Badh2 [173] genes have also been edited through CRISPR/Cas9 for thermo sensitive male sterility, low-Cs+ rice plants, and fragrance characteristics in rice and yielded the expected phenotypes. It was reported that salinity-tolerant rice was improved by engineering a Cas9-OsRR22-gRNA expressing vector to edit the targeted gene OsRR22 [174]. The application of the CRISPR/Cas9 system for simultaneous editing of three genes, OsPIN5b, GS 3, and OsMYB30 was undertaken and reported that the generated rice mutant's lines show outstanding cold tolerance with high grain yield [175]. The application of CRISPR/Cas 9 to create new $O s B A D H 2$ alleles in order to induce fragrance in any non-aromatic rice was also reported [174].

These successful applications of CRISPR-Cas 9 techniques and improvement of rice varieties resistant to abiotic and biotic stresses clearly indicate that genome editing approach such as CRISPR-Cas9 has a huge potential as an accurate, promising, and effective technique for improving more traits [176]. However, there is a need to focus on improving saltresistant rice by editing salinity tolerance genes. SNPs found in GWAS studies that are functionally relevant can be exploited for genome editing [177]. Suppose GWAS is utilized to find the so-called non-phenotypic variations such as expression QTL, methylation QTL, and metabolite QTL, as well as novel and useful alleles. In that case, genome editing can be utilized to assist the combination of new alleles [178]. Such an approach has the potential to revolutionize rice breeding, particularly through genomics-driven crop design. In this review, we emphasize different breeding strategies which can lead to the development of salt-tolerant rice. Figure 2 gives the outline of the integration of different breeding tools for developing salt-tolerant rice varieties.

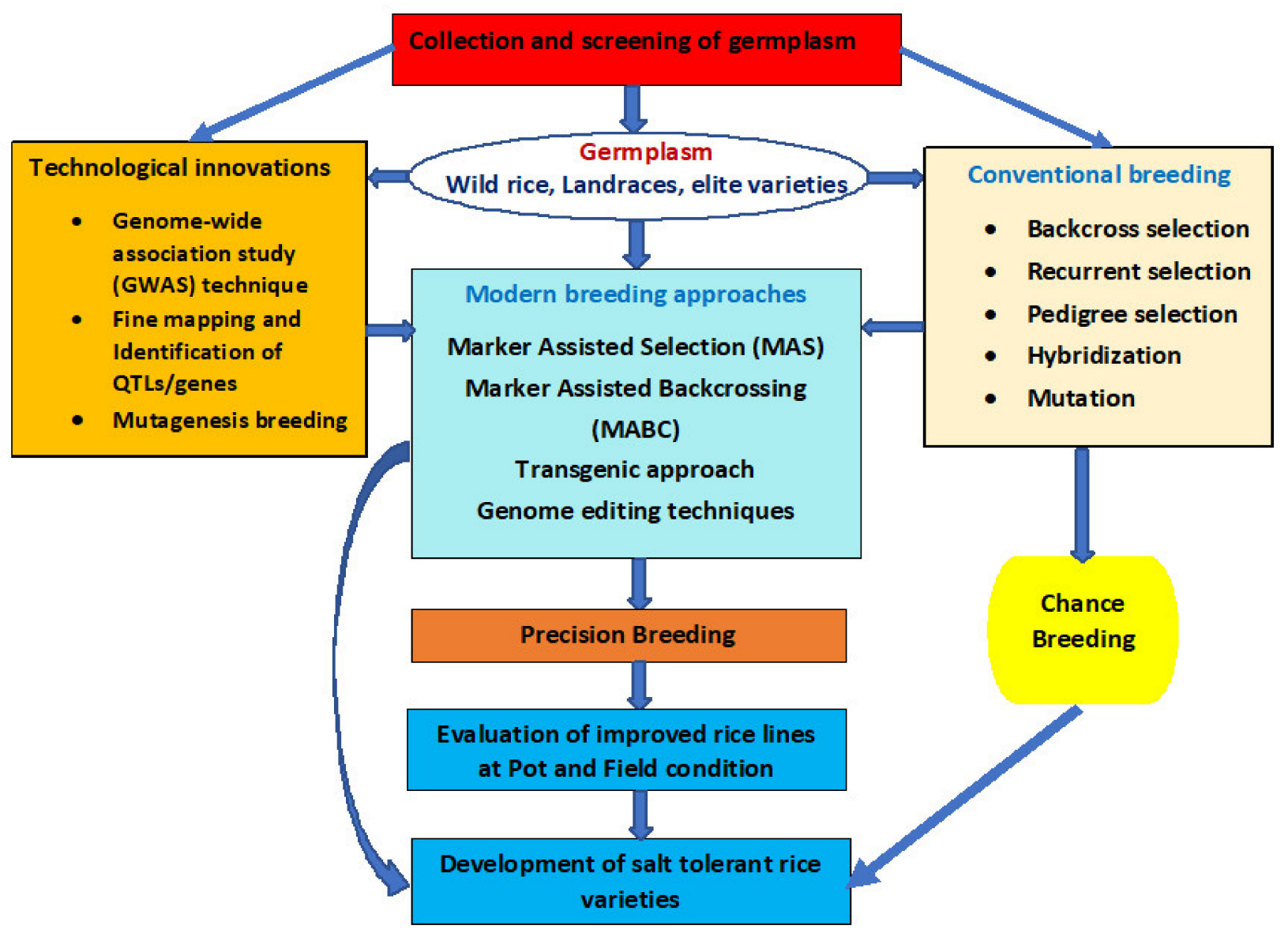

Figure 2. The integration of different breeding tools for developing salt-resilient rice varieties. 


\section{Development of Salt-Resistant Rice Varieties}

The most commercially feasible and ecologically acceptable approach in effectively using saline soil is to develop exceptional salt-tolerant rice cultivars. Yield is an essential agronomic trait for evaluating the benefits of rice types as a food crop. Rice salinity tolerance is described as the capacity to grow with a 0.3 percent saline-alkali concentration and to produce above $4500 \mathrm{~kg}$ rice per hectare. Breeders have spent years scouring the globe for salt-tolerant rice resources, which they have gathered, assessed, and improved. Sri Lanka is the first country to research salinity to screen and identify salt-tolerant rice cultivars. Firstly, Sri Lanka introduced the salt-tolerant rice variety Pokkali in 1939. The IRRI have preserved more than 130,000 rice accessions from different countries around the world. The Philippines has developed salinity-resistant rice varieties. The USA has developed a salt-tolerant variety; American Rice. Bangladesh also breeds salt-tolerant rice cultivars, namely BRRI dhan47, BRRI dhan54, BRRI dhan55, BRRI dhan61, Binadhan-8, and Binadhan-10. Thailand breeds the salt-tolerant variety FL530. Japan breeds salinity-resistant rice cultivars for saline soil management. South Korea has also researched salinity resistance and bred a series of salinity-resistant rice varieties. India largely contributed to managing saline soil by introducing many salt-tolerant rice varieties through the application of conventional and molecular breeding methods. China has also screened and bred salt-tolerant rice varieties, including wild rice, namely Sea Rice 86 and Changmaogu (Table 3).

Table 3. Recently developed salt-tolerant rice varieties through application of different breeding methods in different countries.

\begin{tabular}{|c|c|c|c|c|}
\hline Improved Rice Genotype & $\begin{array}{c}\text { Resistance } \\
\text { Genes/QTLs/Traits }\end{array}$ & Breeding Methods & Country & References \\
\hline Pokkali & Salt resistance & Conventional breeding & Sri Lanka & [179] \\
\hline Nona Bokra, Chin13, Kala Rata, 349 Jhuma & Salinity tolerance & Conventional breeding & Philippines & [180] \\
\hline $\begin{array}{c}\text { BRI, BR203-26-2, BRRI dhan } 47,53,54,55 \text {, and } \\
61 \text {, Binadhan- } 8 \text {, Binadhan- } 10\end{array}$ & Salinity tolerance & Conventional breeding & Bangladesh & {$[100,181]$} \\
\hline FL530 & Salinity tolerance & Conventional breeding & Thailand & [182] \\
\hline $\begin{array}{l}\text { Lansheng, Chikushiqing, Mantaro rice, Hama } \\
\text { Minoru, Kanto } 51\end{array}$ & Salinity tolerance & Conventional breeding & Japan & [180] \\
\hline $\begin{array}{l}\text { Dongjinbyeo, Ganchukbyeo, Gyehwabyeo, } \\
\text { Ilpumbyeo, Seomjimbyeo, Nonganbyeo }\end{array}$ & Salinity tolerance & Conventional breeding & South Korea & [180] \\
\hline VNIIR8207 and Fontan & Salinity tolerance & Conventional breeding & Russia & [180] \\
\hline $\begin{array}{l}\text { Changbai No. 6, 7, 9, 13, Jigeng No. 84, Sea } \\
\text { Rice 86, Changmaogu }\end{array}$ & Salinity tolerance & Conventional breeding & China & [183] \\
\hline Improved Tapaswini & $\begin{array}{l}\text { Sub1, Saltol, Pi2, Pi9, } \\
\text { Gm1, Gm4 }\end{array}$ & MABC * & India & [184] \\
\hline RD6 Rice Variety & ( $q B l 1,2,11$, and 12), Saltol & MABC & India & [185] \\
\hline Improved IR64 & Saltol & MABC & India & [186] \\
\hline Improved Pusa Basmati 1509 & Saltol & MABC & India & [187] \\
\hline Improved Pusa Basmati 1 & Saltol & MABC & India & [188] \\
\hline Improved Pusa44 and Sarjoo 52 & Saltol & MABC & India & [189] \\
\hline Improved Aiswarya & Saltol, Sub1 & MABC & India & [190] \\
\hline Improved PB1121 & Saltol & MABC & India & [103] \\
\hline Improved bengali & Saltol or qSKC1 & MABC & India & [67] \\
\hline Improved white ponni (IWP) & Saltol & MABC & India & [191] \\
\hline Improved IWP & $\begin{array}{c}\text { Saltol or } q S K C 1, q D T Y 1.1 \\
q D T Y 2.1)\end{array}$ & MABC & India & [121] \\
\hline 7PcINO1, 4PcINO1 and 3PcINO1-lines & PcINO1, PcIMT1 & Transgenic approach & India & [192] \\
\hline $\begin{array}{l}\text { OsPP1a-2, OsPP1a-3, } \\
\text { OsPP1a-6 transgenic lines }\end{array}$ & OsPP1a & Transgenic approach & India & [125] \\
\hline Abp57-transgenic rice & Abp57 & Transgenic approach & Malaysia & [193] \\
\hline
\end{tabular}




\section{Conclusions and Future Perspectives}

Salinity stress is the most critical factor among the abiotic stresses influencing rice growth, development, and grain yield production. Developing salt-tolerant rice varieties is one of the most effective and promising solutions to tackle the salinity problem. Researchers have identified some salt-tolerant rice genotypes from the collection and screening of germplasm. This information has built a foundation for rice breeders in understanding salt responsive mechanisms, mapping or identifying QTLs/genes associated with salt stresses for improving salinity resistance rice. The present review addresses recent breeding progress in improving salt tolerance in rice and discusses state-of-the-art tools such as MAS or genetic engineering and genome editing techniques, including mutagenesis and conventional breeding that can help transfer salt-tolerance QTLs/genes into elite rice genotype to accelerate breeding of salinity-stress resistant cultivars. Generally, phenotypic characteristics are employed to measure salt tolerance; however, this method requires thoroughness and precision. As a result, salinity tolerance evaluation differs from actual field performance. Indeed, a consistent technique is critical for determining rice salt tolerance. Numerous QTLs/genes associated with salinity tolerance have been discovered from various mapping populations, but only a few key salt tolerance genes have been identified. QTLs have been limited in breeding programs due to their variability and inconsistency in different genetic origins and environments. Researchers have developed several salt-tolerant rice cultivars using classic breeding methods, but the salt tolerance mechanism remains unknown. These concerns and how plants detect salinity stress, how these signals are converted into adaptive responses, and how numerous salt tolerance genes coordinately regulate salt tolerance in rice require further research. Traditional breeding procedures are inefficient and time-consuming. Molecular breeding methods have been substantially improved by SNP marker-assisted selection and genetic engineering technologies. As a result, more systematic and theoretical analysis on salinity stress is needed to utilize the essential QTLs/genes linked to salt tolerance by transferring into elite rice cultivars through marker aided selection.

Obtaining salt-resistant rice varieties for commercial production by incorporating a single or many genes is difficult. Multiple salinity stress-resistant genes must be transferred into elite rice varieties through marker-assisted gene pyramiding with a view to improving important salt-tolerant rice genotypes. Another problem to overcome is how to transfer these genes quickly and effectively into elite genotypes. Many novel breeding methods, such as genome editing techniques, gene pyramiding, mutmap, and knock-out/in could improve salt-tolerant rice varieties for commercial cultivation. More research should be done on cloning salinity-resistant genes and understanding the regulatory mechanisms of salt responsive genes and looking into how several genes can be introgressed simultaneously with stable inheritance. One of the challenges for all researchers is the limited parental resources for the conventional approach and the complexity of salinity stress. Wild rice species can contribute to breeding salt-tolerant rice varieties using genome editing techniques. Modern breeding tools and strategies such as marker aided selection, genome-wide association, genome editing techniques, and genetic engineering are all rapid advancements in genomic research that can be utilized to improve salt-tolerant rice varieties to minimize the effect of salinity.

Author Contributions: M.A.H., M.Y.R. and M.M.Y. drafted the manuscript, while the proofreading, editing, and finishing were carried out by N.S.A., O.Y., D.R.D., M.A. and M.F.I. All authors offered suggestions on various drafts of the manuscript. All authors have read and agreed to the published version of the manuscript.

Funding: The Higher Institution Centres of Excellence (HICoE), Research Grant (Vot number 6369105), Ministry of Education, Malaysia. The Ministry of Higher Education, Malaysia.

Institutional Review Board Statement: Not applicable.

Informed Consent Statement: Not applicable. 


\section{Data Availability Statement: Not applicable.}

Acknowledgments: We gratefully acknowledge the financial support from the Higher Institution Centres of Excellence (HICoE) Research Grant, the Ministry of Higher Education, Malaysia. The first author also acknowledges the Bangabandhu Science and Technology Fellowship Trust (BBSTFT) under the Ministry of Science and Technology, The People's Republic of Bangladesh, for PhD scholarship.

Conflicts of Interest: We have declared no conflict of interest.

\section{References}

1. Leridon, H.; Population, I. World population outlook: Explosion or implosion? Popul. Soc. 2020, 573, 1-4.

2. Zhu, J.-K. Abiotic Stress Signaling and Responses in Plants. Cell 2016, 167, 313-324. [CrossRef]

3. Shahid, S.A.; Zaman, M.; Heng, L. Soil Salinity: Historical Perspectives and a World Overview of the Problem. In Guideline for Salinity Assessment, Mitigation and Adaptation Using Nuclear and Related Techniques; Springer International Publishing: Cham, Switzerland, 2018; pp. 43-53.

4. Liu, M.; Pan, T.; Allakhverdiev, S.I.; Yu, M.; Shabala, S. Crop Halophytism: An Environmentally Sustainable Solution for Global Food Security. Trends Plant Sci. 2020, 25, 630-634. [CrossRef]

5. Lutts, S.; Kinet, J.M.; Bouharmont, J. Changes in plant response to $\mathrm{NaCl}$ during development of rice (Oryza sativa L.) varieties differing in salinity resistance. J. Exp. Bot. 1995, 46, 1843-1852. [CrossRef]

6. Linh, L.H.; Linh, T.H.; Xuan, T.D.; Ham, L.H.; Ismail, A.M.; Khanh, T.D. Molecular breeding to improve salt tolerance of rice (Oryza sativa L.) in the Red River Delta of Vietnam. Int. J. Plant Genom. 2012, 2012, 949038. [CrossRef]

7. Izawa, T.; Shimamoto, K. Becoming a model plant: The importance of rice to plant science. Trends Plant Sci. 1996, 1, 95-99. [CrossRef]

8. Pareek, A.; Dhankher, O.P.; Foyer, C.H. Mitigating the impact of climate change on plant productivity and ecosystem sustainability. J. Exp. Bot. 2020, 71, 451-456. [CrossRef] [PubMed]

9. Kotula, L.; Garcia Caparros, P.; Zörb, C.; Colmer, T.D.; Flowers, T.J. Improving crop salt tolerance using transgenic approaches: An update and physiological analysis. Plant. Cell Environ. 2020, 43, 2932-2956. [CrossRef] [PubMed]

10. Liu, M.; Yu, H.; Ouyang, B.; Shi, C.; Demidchik, V.; Hao, Z.; Yu, M.; Shabala, S. NADPH oxidases and the evolution of plant salinity tolerance. Plant Cell Environ. 2020, 43, 2957-2968. [CrossRef] [PubMed]

11. Tsai, Y.-C.; Chen, K.-C.; Cheng, T.-S.; Lee, C.; Lin, S.-H.; Tung, C.-W. Chlorophyll fluorescence analysis in diverse rice varieties reveals the positive correlation between the seedlings salt tolerance and photosynthetic efficiency. BMC Plant Biol. $2019,19,403$. [CrossRef]

12. Chinnusamy, V.; Jagendorf, A.; Zhu, J. Understanding and Improving Salt Tolerance in Plants. Crop Sci. 2005, 45, 437-448. [CrossRef]

13. Todaka, D.; Nakashima, K.; Shinozaki, K.; Yamaguchi-Shinozaki, K. Toward understanding transcriptional regulatory networks in abiotic stress responses and tolerance in rice. Rice 2012, 5, 6. [CrossRef] [PubMed]

14. Lee, K.-S.; Choi, W.-Y.; Ko, J.-C.; Kim, T.-S.; Gregorio, G.B. Salinity tolerance of japonica and indica rice (Oryza sativa L.) at the seedling stage. Planta 2003, 216, 1043-1046. [CrossRef] [PubMed]

15. Singh, A.K.; Ansari, M.W.; Pareek, A.; Singla-Pareek, S.L. Raising salinity tolerant rice: Recent progress and future perspectives. Physiol. Mol. Biol. Plants 2008, 14, 137-154. [CrossRef] [PubMed]

16. Zeng, L.; Lesch, S.M.; Grieve, C.M. Rice growth and yield respond to changes in water depth and salinity stress. Agric. Water Manag. 2003, 59, 67-75. [CrossRef]

17. Rao, P.S.; Mishra, B.; Gupta, S.R.; Rathore, A. Reproductive stage tolerance to salinity and alkalinity stresses in rice genotypes. Plant Breed. 2008, 127, 256-261. [CrossRef]

18. Ren, Z.-H.; Gao, J.-P.; Li, L.-G.; Cai, X.-L.; Huang, W.; Chao, D.-Y.; Zhu, M.-Z.; Wang, Z.-Y.; Luan, S.; Lin, H.-X. A rice quantitative trait locus for salt tolerance encodes a sodium transporter. Nat. Genet. 2005, 37, 1141-1146. [CrossRef]

19. Flowers, T.J.; Flowers, S.A. Why does salinity pose such a difficult problem for plant breeders? Agric. Water Manag. 2005, 78, 15-24. [CrossRef]

20. Negrão, S.; Schmöckel, S.M.; Tester, M. Evaluating physiological responses of plants to salinity stress. Ann. Bot. 2017, 119, 1-11. [CrossRef]

21. Saeed, M. Abiotic Stress Tolerance in Rice (Oryza sativa L.): A Genomics Perspective of Salinity Tolerance. In Rice Crop-Current Developments; InTech: London, UK, 2018; pp. 181-192.

22. Razzaq, A.; Ali, A.; Safdar, L.B.; Zafar, M.M.; Rui, Y.; Shakeel, A.; Shaukat, A.; Ashraf, M.; Gong, W.; Yuan, Y. Salt stress induces physiochemical alterations in rice grain composition and quality. J. Food Sci. 2020, 85, 14-20. [CrossRef]

23. Saleethong, P.; Sanitchon, J.; Kong-ngern, K.; Theerakulpisut, P. Effects of exogenous spermidine (Spd) on yield, yield-related parameters and mineral composition of rice (Oryza sativa L. ssp. indica) grains under salt stress. Aust. J. Crop Sci. 2013, 7, 1293-1301.

24. Verma, T.S.; Neue, H.U. Effect of soil salinity level and zinc application on growth, yield, and nutrient composition of rice. Plant Soil 1984, 82, 3-14. [CrossRef] 
25. Solis, C.A.; Yong, M.T.; Vinarao, R.; Jena, K.; Holford, P.; Shabala, L.; Zhou, M.; Shabala, S.; Chen, Z.-H. Back to the Wild: On a Quest for Donors Toward Salinity Tolerant Rice. Front. Plant Sci. 2020, 11, 323. [CrossRef] [PubMed]

26. Mishra, M.; Wungrampha, S.; Kumar, G.; Singla-Pareek, S.L.; Pareek, A. How do rice seedlings of landrace Pokkali survive in saline fields after transplantation? Physiology, biochemistry, and photosynthesis. Photosynth. Res. 2020. [CrossRef]

27. Shi, Y.; Gao, L.; Wu, Z.; Zhang, X.; Wang, M.; Zhang, C.; Zhang, F.; Zhou, Y.; Li, Z. Genome-wide association study of salt tolerance at the seed germination stage in rice. BMC Plant Biol. 2017, 17, 92. [CrossRef] [PubMed]

28. Gregorio, G.B.; Senadhira, D.; Mendoza, R.D. Screening Rice for Salinity Tolerance; Discussion Paper Series; International Rice Research Institute: Manila, Philippines, 1997.

29. Yeo, A.R.; Yeo, M.E.; Flowers, S.A.; Flowers, T.J. Screening of rice (Oryza sativa L.) genotypes for physiological characters contributing to salinity resistance, and their relationship to overall performance. Theor. Appl. Genet. 1990, 79, 377-384. [CrossRef]

30. Al-Tamimi, N.; Brien, C.; Oakey, H.; Berger, B.; Saade, S.; Ho, Y.S.; Schmöckel, S.M.; Tester, M.; Negrão, S. Salinity tolerance loci revealed in rice using high-throughput non-invasive phenotyping. Nat. Commun. 2016, 7, 13342. [CrossRef]

31. Platten, J.D.; Egdane, J.A.; Ismail, A.M. Salinity tolerance, Na+ exclusion and allele mining of HKT1;5 in Oryza sativa and O. glaberrima: Many sources, many genes, one mechanism? BMC Plant Biol. 2013, 13, 32. [CrossRef] [PubMed]

32. Mishra, S.; Singh, B.; Panda, K.; Singh, B.P.; Singh, N.; Misra, P.; Rai, V.; Singh, N.K. Association of SNP Haplotypes of HKT Family Genes with Salt Tolerance in Indian Wild Rice Germplasm. Rice 2016, 9, 15. [CrossRef]

33. Munns, R.; Tester, M. Mechanisms of salinity tolerance. Annu. Rev. Plant Biol. 2008, 59, 651-681. [CrossRef]

34. Sun, B.-R.; Fu, C.-Y.; Fan, Z.-L.; Chen, Y.; Chen, W.-F.; Zhang, J.; Jiang, L.-Q.; Lv, S.; Pan, D.-J.; Li, C. Genomic and transcriptomic analysis reveal molecular basis of salinity tolerance in a novel strong salt-tolerant rice landrace Changmaogu. Rice 2019, 12, 99. [CrossRef]

35. Chen, R.; Cheng, Y.; Han, S.; Van Handel, B.; Dong, L.; Li, X.; Xie, X. Whole genome sequencing and comparative transcriptome analysis of a novel seawater adapted, salt-resistant rice cultivar-Sea rice 86. BMC Genom. 2017, 18, 655. [CrossRef]

36. Prusty, M.R.; Kim, S.-R.; Vinarao, R.; Entila, F.; Egdane, J.; Diaz, M.G.Q.; Jena, K.K. Newly Identified Wild Rice Accessions Conferring High Salt Tolerance Might Use a Tissue Tolerance Mechanism in Leaf. Front. Plant Sci. 2018, 9, 417. [CrossRef]

37. Rajakani, R.; Sellamuthu, G.; Saravanakumar, V.; Kannappan, S.; Shabala, L.; Meinke, H.; Chen, Z.; Zhou, M.; Parida, A.; Shabala, S.; et al. Microhair on the adaxial leaf surface of salt secreting halophytic Oryza coarctata Roxb. show distinct morphotypes: Isolation for molecular and functional analysis. Plant Sci. 2019, 285, 248-257. [CrossRef] [PubMed]

38. Majee, M.; Maitra, S.; Dastidar, K.G.; Pattnaik, S.; Chatterjee, A.; Hait, N.C.; Das, K.P.; Majumder, A.L. A Novel Salt-tolerant 1-myo-Inositol-1-phosphate Synthase from Porteresia coarctata (Roxb.) Tateoka, a Halophytic Wild Rice. J. Biol. Chem. 2004, 279, 28539-28552. [CrossRef]

39. Huang, X.-Y.; Chao, D.-Y.; Gao, J.-P.; Zhu, M.-Z.; Shi, M.; Lin, H.-X. A previously unknown zinc finger protein, DST, regulates drought and salt tolerance in rice via stomatal aperture control. Genes Dev. 2009, 23, 1805-1817. [CrossRef] [PubMed]

40. Takagi, H.; Tamiru, M.; Abe, A.; Yoshida, K.; Uemura, A.; Yaegashi, H.; Obara, T.; Oikawa, K.; Utsushi, H.; Kanzaki, E.; et al. MutMap accelerates breeding of a salt-tolerant rice cultivar. Nat. Biotechnol. 2015, 33, 445-449. [CrossRef] [PubMed]

41. Ismail, A.M.; Horie, T. Genomics, Physiology, and Molecular Breeding Approaches for Improving Salt Tolerance. Annu. Rev. Plant Biol. 2017, 68, 405-434. [CrossRef]

42. Lin, H.X.; Zhu, M.Z.; Yano, M.; Gao, J.P.; Liang, Z.W.; Su, W.A.; Hu, X.H.; Ren, Z.H.; Chao, D.Y. QTLs for $\mathrm{Na}^{+}$and $\mathrm{K}^{+}$uptake of the shoots and roots controlling rice salt tolerance. Theor. Appl. Genet. 2004, 108, 253-260. [CrossRef]

43. Thomson, M.J.; de Ocampo, M.; Egdane, J.; Rahman, M.A.; Sajise, A.G.; Adorada, D.L.; Tumimbang-Raiz, E.; Blumwald, E.; Seraj, Z.I.; Singh, R.K.; et al. Characterizing the Saltol Quantitative Trait Locus for Salinity Tolerance in Rice. Rice 2010, 3, 148-160. [CrossRef]

44. He, Y.; Yang, B.; He, Y.; Zhan, C.; Cheng, Y.; Zhang, J.; Zhang, H.; Cheng, J.; Wang, Z. A quantitative trait locus, qSE 3, promotes seed germination and seedling establishment under salinity stress in rice. Plant J. 2019, 97, 1089-1104. [CrossRef] [PubMed]

45. Lee, S.Y.; Ahn, J.H.; Cha, Y.S.; Yun, D.W.; Lee, M.C.; Ko, J.C.; Lee, K.S.; Eun, M.Y. Mapping QTLs related to salinity tolerance of rice at the young seedling stage. Plant Breed. 2007, 126, 43-46. [CrossRef]

46. Wu, F.; Yang, J.; Yu, D.; Xu, P. Identification and Validation a Major QTL from "Sea Rice 86" Seedlings Conferred Salt Tolerance. Agronomy 2020, 10, 410. [CrossRef]

47. Wang, G.-F.; Li, W.-Q.; Li, W.-Y.; Wu, G.-L.; Zhou, C.-Y.; Chen, K.-M. Characterization of Rice NADPH Oxidase Genes and Their Expression under Various Environmental Conditions. Int. J. Mol. Sci. 2013, 14, 9440-9458. [CrossRef] [PubMed]

48. Asada, K. The Water-Water Cycle in Chloroplasts: Scavenging of Active Oxygens and Dissipation of Excess Photons. Annu. Rev. Plant Physiol. Plant Mol. Biol. 1999, 50, 601-639. [CrossRef] [PubMed]

49. Ouyang, S.; He, S.; Liu, P.; Zhang, W.; Zhang, J.; Chen, S. The role of tocopherol cyclase in salt stress tolerance of rice (Oryza sativa). Sci. China Life Sci. 2011, 54, 181-188. [CrossRef]

50. Zhang, Z.; Zhang, Q.; Wu, J.; Zheng, X.; Zheng, S.; Sun, X.; Qiu, Q.; Lu, T. Gene Knockout Study Reveals That Cytosolic Ascorbate Peroxidase 2(OsAPX2) Plays a Critical Role in Growth and Reproduction in Rice under Drought, Salt and Cold Stresses. PLoS ONE 2013, 8, e57472. [CrossRef]

51. Campbell, M.T.; Bandillo, N.; Al Shiblawi, F.R.A.; Sharma, S.; Liu, K.; Du, Q.; Schmitz, A.J.; Zhang, C.; Véry, A.-A.; Lorenz, A.J.; et al. Allelic variants of OsHKT1;1 underlie the divergence between indica and japonica subspecies of rice (Oryza sativa) for root sodium content. PLoS Genet. 2017, 13, e1006823. [CrossRef] [PubMed] 
52. Ganie, S.A.; Molla, K.A.; Henry, R.J.; Bhat, K.V.; Mondal, T.K. Advances in understanding salt tolerance in rice. Theor. Appl. Genet. 2019, 132, 851-870. [CrossRef]

53. Jadamba, C.; Kang, K.; Paek, N.-C.; Lee, S.I.; Yoo, S.-C. Overexpression of Rice Expansin7 (Osexpa7) Confers Enhanced Tolerance to Salt Stress in Rice. Int. J. Mol. Sci. 2020, 21, 454. [CrossRef]

54. Zhou, J.; Li, Z.; Xiao, G.; Zhai, M.; Pan, X.; Huang, R.; Zhang, H. OsCYP71D8L as a key regulator involved in growth and stress response by mediating gibberellins homeostasis in rice. J. Exp. Bot. 2019, 71, 1160-1170. [CrossRef]

55. Wang, J.; Qin, H.; Zhou, S.; Wei, P.; Zhang, H.; Zhou, Y.; Miao, Y.; Huang, R. The Ubiquitin-Binding Protein OsDSK2a Mediates Seedling Growth and Salt Responses by Regulating Gibberellin Metabolism in Rice. Plant Cell 2020, 32, 414-428. [CrossRef]

56. Sanchouli, S.; Neghab, M.G.; Sabouri, H.; Mehrjerdi, M.Z. Genetic Structure of Salinity Tolerance in Rice at Seedling Stage. J. Genet. Resour. 2019, 5, 22-30. [CrossRef]

57. Lei, L.; Zheng, H.; Bi, Y.; Yang, L.; Liu, H.; Wang, J.; Sun, J.; Zhao, H.; Li, X.; Li, J.; et al. Identification of a Major QTL and Candidate Gene Analysis of Salt Tolerance at the Bud Burst Stage in Rice (Oryza sativa L.) Using QTL-Seq and RNA-Seq. Rice 2020, 13, 55. [CrossRef]

58. Rahman, M.A.; Thomson, M.J.; De Ocampo, M.; Egdane, J.A.; Salam, M.A.; Shah-E-Alam, M.; Ismail, A.M. Assessing trait contribution and mapping novel QTL for salinity tolerance using the Bangladeshi rice landrace Capsule. Rice 2019, 12, 63. [CrossRef] [PubMed]

59. Amoah, N.K.A.; Akromah, R.; Kena, A.W.; Manneh, B.; Dieng, I.; Bimpong, I.K. Mapping QTLs for tolerance to salt stress at the early seedling stage in rice (Oryza sativa L.) using a newly identified donor 'Madina Koyo'. Euphytica 2020, 216, 156. [CrossRef]

60. Jahan, N.; Zhang, Y.; Lv, Y.; Song, M.; Zhao, C.; Hu, H.; Cui, Y.; Wang, Z.; Yang, S.; Zhang, A.; et al. QTL analysis for rice salinity tolerance and fine mapping of a candidate locus qSL7 for shoot length under salt stress. Plant Growth Regul. 2020, 90, 307-319. [CrossRef]

61. Ghomi, K.; Rabiei, B.; Sabouri, H.; Sabouri, A. Mapping QTLs for Traits Related to Salinity Tolerance at Seedling Stage of Rice (Oryza sativa L.): An Agrigenomics Study of an Iranian Rice Population. Omics A J. Integr. Biol. 2013, 17, 242-251. [CrossRef] [PubMed]

62. Chen, T.; Zhu, Y.; Chen, K.; Shen, C.; Zhao, X.; Shabala, S.; Shabala, L.; Meinke, H.; Venkataraman, G.; Chen, Z.; et al. Identification of new QTL for salt tolerance from rice variety Pokkali. J. Agron. Crop Sci. 2020, 206, 202-213. [CrossRef]

63. Wang, Z.; Wang, J.; Bao, Y.; Wu, Y.; Zhang, H. Quantitative trait loci controlling rice seed germination under salt stress. Euphytica 2011, 178, 297-307. [CrossRef]

64. Puram, V.R.R.; Ontoy, J.; Subudhi, P.K. Identification of QTLs for Salt Tolerance Traits and Prebreeding Lines with Enhanced Salt Tolerance in an Introgression Line Population of Rice. Plant Mol. Biol. Report. 2018, 36, 695-709. [CrossRef]

65. Wang, S.; Cao, M.; Ma, X.; Chen, W.; Zhao, J.; Sun, C.; Tan, L.; Liu, F. Integrated RNA Sequencing and QTL Mapping to Identify Candidate Genes from Oryza rufipogon Associated with Salt Tolerance at the Seedling Stage. Front. Plant Sci. 2017, 8, 1427. [CrossRef] [PubMed]

66. De Leon, T.B.; Linscombe, S.; Subudhi, P.K. Identification and validation of QTLs for seedling salinity tolerance in introgression lines of a salt tolerant rice landrace 'Pokkali'. PLoS ONE 2017, 12, e0175361. [CrossRef] [PubMed]

67. Kim, D.-M.; Ju, H.-G.; Kwon, T.-R.; Oh, C.-S.; Ahn, S.-N. Mapping QTLs for salt tolerance in an introgression line population between Japonica cultivars in rice. J. Crop Sci. Biotechnol. 2009, 12, 121-128. [CrossRef]

68. Liang, J.; Qu, Y.; Yang, C.; Ma, X.; Cao, G.; Zhao, Z.; Zhang, S.; Zhang, T.; Han, L. Identification of QTLs associated with salt or alkaline tolerance at the seedling stage in rice under salt or alkaline stress. Euphytica 2015, 201, 441-452. [CrossRef]

69. Sabouri, H.; Rezai, A.M.; Moumeni, A.; Kavousi, A.; Katouzi, M.; Sabouri, A. QTLs mapping of physiological traits related to salt tolerance in young rice seedlings. Biol. Plant. 2009, 53, 657-662. [CrossRef]

70. Mohammadi, R.; Mendioro, M.S.; Diaz, G.Q.; Gregorio, G.B.; Singh, R.K. Mapping quantitative trait loci associated with yield and yield components under reproductive stage salinity stress in rice (Oryza sativa L.). J. Genet. 2013, 92, 433-443. [PubMed]

71. Ammar, M.H.M.; Pandit, A.; Singh, R.K.; Sameena, S.; Chauhan, M.S.; Singh, A.K.; Sharma, P.C.; Gaikwad, K.; Sharma, T.R.; Mohapatra, T.; et al. Mapping of QTLs Controlling Na+, K+ and CI- Ion Concentrations in Salt Tolerant Indica Rice Variety CSR27. J. Plant Biochem. Biotechnol. 2009, 18, 139-150. [CrossRef]

72. Rahman, M.A.; Bimpong, I.K.; Bizimana, J.B.; Pascual, E.D.; Arceta, M.; Swamy, B.P.M.; Diaw, F.; Rahman, M.S.; Singh, R.K. Mapping QTLs using a novel source of salinity tolerance from Hasawi and their interaction with environments in rice. Rice 2017, 10, 47. [CrossRef]

73. Lang, N.T.; Phuoc, N.T.; Ha, P.T.T.; Buu, B.C. Identifying QTLs Associated and Marker-Assisted Selection for Salinity Tolerance at the Seedling, Vegetative and Reproductive Stages in Rice (Oryza sativa L.). Int. J. Environ. Agric. Biotechnol. 2017, 2, $2927-2935$. [CrossRef]

74. Ocampo, M.; The, H.V.; Thomson, M.; Mitsuya, S.; Yamauchi, A.; Ismail, A. QTL mapping and candidate gene identification in rice using a Kalarata-Azucena population under salt stress. Res. Squre 2020, 1-36. [CrossRef]

75. Zeng, P.; Zhu, P.; Qian, L.; Qian, X.; Mi, Y.; Lin, Z.; Dong, S.; Aronsson, H.; Zhang, H.; Cheng, J. Identification and fine mapping of qGR6.2, a novel locus controlling rice seed germination under salt stress. BMC Plant Biol. 2021, 21, 36. [CrossRef]

76. Haque, T.; Elias, S.M.; Razzaque, S.; Biswas, S.; Khan, S.F.; Jewel, G.M.N.A.; Rahman, S.; Juenger, T.E.; Seraj, Z.I. Natural Variation in Growth and Physiology under Salt Stress in Rice: QTL Mapping in a Horkuch $\times$ IR29 Mapping Population at Seedling and Reproductive Stages. bioRxiv 2020, 2507. [CrossRef] 
77. Li, H.-W.; Zang, B.-S.; Deng, X.-W.; Wang, X.-P. Overexpression of the trehalose-6-phosphate synthase gene OsTPS1 enhances abiotic stress tolerance in rice. Planta 2011, 234, 1007-1018. [CrossRef] [PubMed]

78. Lan, T.; Zheng, Y.; Su, Z.; Yu, S.; Song, H.; Zheng, X.; Lin, G.; Wu, W. OsSPL10, a SBP-Box Gene, Plays a Dual Role in Salt Tolerance and Trichome Formation in Rice (Oryza sativa L.). G3 Genes Genomes Genet. 2019, 9, 4107-4114. [CrossRef] [PubMed]

79. Tang, Y.; Bao, X.; Zhi, Y.; Wu, Q.; Guo, Y.; Yin, X.; Zeng, L.; Li, J.; Zhang, J.; He, W.; et al. Overexpression of a MYB Family Gene, OsMYB6, Increases Drought and Salinity Stress Tolerance in Transgenic Rice. Front. Plant Sci. 2019, 10, 168. [CrossRef]

80. Xu, N.; Chu, Y.; Chen, H.; Li, X.; Wu, Q.; Jin, L.; Wang, G.; Huang, J. Rice transcription factor OsMADS25 modulates root growth and confers salinity tolerance via the ABA-mediated regulatory pathway and ROS scavenging. PLoS Genet. 2018, 14, e1007662. [CrossRef] [PubMed]

81. Zhang, Y.; Fang, J.; Wu, X.; Dong, L. Na+/K+ Balance and Transport Regulatory Mechanisms in Weedy and Cultivated Rice (Oryza sativa L.) Under Salt Stress. BMC Plant Biol. 2018, 18, 375. [CrossRef] [PubMed]

82. Qin, H.; Wang, J.; Chen, X.; Wang, F.; Peng, P.; Zhou, Y.; Miao, Y.; Zhang, Y.; Gao, Y.; Qi, Y.; et al. Rice OsDOF15 contributes to ethylene-inhibited primary root elongation under salt stress. New Phytol. 2019, 223, 798-813. [CrossRef]

83. Shan, C.; Mei, Z.; Duan, J.; Chen, H.; Feng, H.; Cai, W. OsGA2ox5, a Gibberellin Metabolism Enzyme, Is Involved in Plant Growth, the Root Gravity Response and Salt Stress. PLoS ONE 2014, 9, e87110. [CrossRef]

84. Saijo, Y.; Hata, S.; Kyozuka, J.; Shimamoto, K.; Izui, K. Over-expression of a single Ca 2+ -dependent protein kinase confers both cold and salt/drought tolerance on rice plants. Plant J. 2000, 23, 319-327. [CrossRef]

85. Asano, T.; Hakata, M.; Nakamura, H.; Aoki, N.; Komatsu, S.; Ichikawa, H.; Hirochika, H.; Ohsugi, R. Functional characterisation of OsCPK21, a calcium-dependent protein kinase that confers salt tolerance in rice. Plant Mol. Biol. 2011, 75, 179-191. [CrossRef]

86. Asano, T.; Hayashi, N.; Kobayashi, M.; Aoki, N.; Miyao, A.; Mitsuhara, I.; Ichikawa, H.; Komatsu, S.; Hirochika, H.; Kikuchi, S.; et al. A rice calcium-dependent protein kinase OsCPK12 oppositely modulates salt-stress tolerance and blast disease resistance. Plant J. 2012, 69, 26-36. [CrossRef] [PubMed]

87. Saeng-ngam, S.; Takpirom, W.; Buaboocha, T.; Chadchawan, S. The role of the OsCam1-1 salt stress sensor in ABA accumulation and salt tolerance in rice. J. Plant Biol. 2012, 55, 198-208. [CrossRef]

88. Xu, G.-Y.; Rocha, P.S.C.F.; Wang, M.-L.; Xu, M.-L.; Cui, Y.-C.; Li, L.-Y.; Zhu, Y.-X.; Xia, X. A novel rice calmodulin-like gene, OsMSR2, enhances drought and salt tolerance and increases ABA sensitivity in Arabidopsis. Planta 2011, 234, 47-59. [CrossRef] [PubMed]

89. Shi, C.-C.; Feng, C.-C.; Yang, M.-M.; Li, J.-L.; Li, X.-X.; Zhao, B.-C.; Huang, Z.-J.; Ge, R.-C. Overexpression of the receptor-like protein kinase genes AtRPK1 and OsRPK1 reduces the salt tolerance of Arabidopsis thaliana. Plant Sci. 2014, 217-218, 63-70. [CrossRef]

90. McCouch, S.R.; Wright, M.H.; Tung, C.-W.; Maron, L.G.; McNally, K.L.; Fitzgerald, M.; Singh, N.; DeClerck, G.; Agosto-Perez, F.; Korniliev, P.; et al. Open access resources for genome-wide association mapping in rice. Nat. Commun. 2016, 7, 10532. [CrossRef] [PubMed]

91. Lu, Q.; Zhang, M.; Niu, X.; Wang, S.; Xu, Q.; Feng, Y.; Wang, C.; Deng, H.; Yuan, X.; Yu, H.; et al. Genetic variation and association mapping for 12 agronomic traits in indica rice. BMC Genom. 2015, 16, 1067. [CrossRef]

92. Burghardt, L.T.; Young, N.D.; Tiffin, P. A Guide to Genome-Wide Association Mapping in Plants. Curr. Protoc. Plant Biol. 2017, 2, 22-38. [CrossRef] [PubMed]

93. Huang, X.; Han, B. Natural Variations and Genome-Wide Association Studies in Crop Plants. Annu. Rev. Plant Biol. 2014, 65, 531-551. [CrossRef]

94. Yadav, A.K.; Kumar, A.; Grover, N.; Ellur, R.K.; Bollinedi, H.; Krishnan, S.G.; Bhowmick, P.K.; Vinod, K.K.; Nagarajan, M.; Singh, A.K. Genome-Wide Association Study Reveals Marker-Trait Associations for Early Vegetative Stage Salinity Tolerance in Rice. Plants 2021, 10, 559. [CrossRef]

95. Naveed, S.A.; Zhang, F.; Zhang, J.; Zheng, T.-Q.; Meng, L.-J.; Pang, Y.-L.; Xu, J.-L.; Li, Z.-K. Identification of QTN and candidate genes for Salinity Tolerance at the Germination and Seedling Stages in Rice by Genome-Wide Association Analyses. Sci. Rep. 2018, 8, 6505. [CrossRef]

96. Cui, Y.; Zhang, F.; Zhou, Y. The Application of Multi-Locus GWAS for the Detection of Salt-Tolerance Loci in Rice. Front. Plant Sci. 2018, 9, 1464. [CrossRef]

97. Liu, C.; Chen, K.; Zhao, X.; Wang, X.; Shen, C.; Zhu, Y.; Dai, M.; Qiu, X.; Yang, R.; Xing, D.; et al. Identification of genes for salt tolerance and yield-related traits in rice plants grown hydroponically and under saline field conditions by genome-wide association study. Rice 2019, 12, 88. [CrossRef] [PubMed]

98. Chen, C.; Norton, G.J.; Price, A.H. Genome-Wide Association Mapping for Salt Tolerance of Rice Seedlings Grown in Hydroponic and Soil Systems Using the Bengal and Assam Aus Panel. Front. Plant Sci. 2020, 11, 1633. [CrossRef]

99. Rahman, M.A.; Thomson, M.J.; Shah-E-Alam, M.; De Ocampo, M.; Egdane, J.; Ismail, A.M. Exploring novel genetic sources of salinity tolerance in rice through molecular and physiological characterization. Ann. Bot. 2016, 117, 1083-1097. [CrossRef]

100. Chukwu, S.C.; Rafii, M.Y.; Ramlee, S.I.; Ismail, S.I.; Oladosu, Y.; Kolapo, K.; Musa, I.; Halidu, J.; Muhammad, I.; Ahmed, M. Marker-Assisted Introgression of Multiple Resistance Genes Confers Broad Spectrum Resistance against Bacterial Leaf Blight and Blast Diseases in PUTRA-1 Rice Variety. Agronomy 2019, 10, 42. [CrossRef]

101. Reynolds, M.; Dreccer, F.; Trethowan, R. Drought-adaptive traits derived from wheat wild relatives and landraces. J. Exp. Bot. 2006, 58, 177-186. [CrossRef] [PubMed] 
102. Babu, N.N.; Krishnan, S.G.; Vinod, K.K.; Krishnamurthy, S.L.; Singh, V.K.; Singh, M.P.; Singh, R.; Ellur, R.K.; Rai, V.; Bollinedi, H.; et al. Marker aided incorporation of saltol, a major QTL associated with seedling stage salt tolerance, into Oryza sativa 'pusa basmati 1121'. Front. Plant Sci. 2017, 8, 1-14. [CrossRef]

103. Chukwu, S.C.; Rafii, M.Y.; Ramlee, S.I.; Ismail, S.I.; Oladosu, Y.; Okporie, E.; Onyishi, G.; Utobo, E.; Ekwu, L.; Swaray, S.; et al. Marker-assisted selection and gene pyramiding for resistance to bacterial leaf blight disease of rice (Oryza sativa L.). Biotechnol. Biotechnol. Equip. 2019, 33, 440-455. [CrossRef]

104. Singh, S.; Sidhu, J.S.; Huang, N.; Vikal, Y.; Li, Z.; Brar, D.S.; Dhaliwal, H.S.; Khush, G.S. A Critical Review of Submergence Tolerance Breeding Beyond Sub 1 Gene to Mega Varieties in the Context of Climate Change. Int. J. Adv. Sci. Res. Eng. 2018, 102, 1011-1015. [CrossRef]

105. Singh, R.; Singh, Y.; Xalaxo, S.; Verulkar, S.; Yadav, N.; Singh, S.; Singh, N.; Prasad, K.S.N.; Kondayya, K.; Rao, P.V.R.; et al. From QTL to variety-harnessing the benefits of QTLs for drought, flood and salt tolerance in mega rice varieties of India through a multi-institutional network. Plant Sci. 2016, 242, 278-287. [CrossRef] [PubMed]

106. Mani, B.R.; Kumar, B.M.D.; Krishnamurthy, S.L. Genetic variability and diversity of rice landraces of South Western India based on morphological traits. ORYZA 2014, 51, 261-266.

107. Khan, M.S.K.; Saeed, M.; Iqbal, J. Quantitative trait locus mapping for salt tolerance at maturity stage in indica rice using replicated F2 population. Rev. Bras. Bot. 2016, 39, 641-650. [CrossRef]

108. Khan, M.S.K.; Saeed, M.; Iqbal, J. Identification of quantitative trait loci for $\mathrm{Na}+, \mathrm{K}+$ and $\mathrm{Ca}++$ accumulation traits in rice grown under saline conditions using F2 mapping population. Braz. J. Bot. 2015, 38, 555-565. [CrossRef]

109. Koyama, M.L.; Levesley, A.; Koebner, R.M.D.; Flowers, T.J.; Yeo, A.R. Quantitative Trait Loci for Component Physiological Traits Determining Salt Tolerance in Rice. Plant Physiol. 2001, 125, 406-422. [CrossRef]

110. Kumar, V.; Singh, A.; Mithra, S.V.A.; Krishnamurthy, S.L.; Parida, S.K.; Jain, S.; Tiwari, K.K.; Kumar, P.; Rao, A.R.; Sharma, S.K.; et al. Genome-wide association mapping of salinity tolerance in rice (Oryza sativa). DNA Res. 2015, 22, 133-145. [CrossRef] [PubMed]

111. Kurokawa, Y.; Noda, T.; Yamagata, Y.; Angeles-Shim, R.; Sunohara, H.; Uehara, K.; Furuta, T.; Nagai, K.; Jena, K.K.; Yasui, H.; et al. Construction of a versatile SNP array for pyramiding useful genes of rice. Plant Sci. 2016, 242, 131-139. [CrossRef] [PubMed]

112. Molla, K.A.; Debnath, A.B.; Ganie, S.A.; Mondal, T.K. Identification and analysis of novel salt responsive candidate gene based SSRs (cgSSRs) from rice (Oryza sativa L.). BMC Plant Biol. 2015, 15, 122. [CrossRef]

113. Tiwari, S.; SL, K.; Kumar, V.; Singh, B.; Rao, A.; Mithra SV, A.; Rai, V.; Singh, A.K.; Singh, N.K. Mapping QTLs for Salt Tolerance in Rice (Oryza sativa L.) by Bulked Segregant Analysis of Recombinant Inbred Lines Using 50K SNP Chip. PLoS ONE 2016, 11, e0153610. [CrossRef]

114. Rahman, S.; Haque, T.; Rahman, M.S.; Seraj, Z. Salt Tolerant BR11 and Salt Tolerant BR28 through Marker Assisted Backcrossing (MAB). In Proceedings of the International Scientific Conference on "50 Years of Biochemis-Crop Breeding for Salt Tolerance in the Era of Molecular Markers 19 Try in Bangladesh: Successes and Prospects"; Bangladesh Society for Biochemistrsy and Molecular Biology: Dhaka, Banglades, 2008; Volume 50.

115. Huyen, L.T.N.; Cuc, L.M.; Ismail, A.M.; Ham, L.H. Introgression the Salinity Tolerance QTLs Saltol into AS996, the Elite Rice Variety of Vietnam. Am. J. Plant Sci. 2012, 3, 981-987. [CrossRef]

116. Bimpong, I.K.; Manneh, B.; Sock, M.; Diaw, F.; Amoah, N.K.A.; Ismail, A.M.; Gregorio, G.; Singh, R.K.; Wopereis, M. Improving salt tolerance of lowland rice cultivar 'Rassi' through marker-aided backcross breeding in West Africa. Plant Sci. 2016, 242, 288-299. [CrossRef]

117. Singh, A.K.; Gopalakrishnan, S.; Singh, V.P.; Prabhu, K.V.; Mohapatra, T.; Singh, N.K.; Sharma, T.R.; Nagarajan, M.; Ellur, R.K.; Singh, A.; et al. Marker assisted selection: A paradigm shift in Basmati breeding. Indian J. Genet. Plant Breed. $2011,71,120$.

118. Geetha, S.; Vasuki, A.; Selvam, P.J.; Saraswathi, R.; Krishnamurthy, S.L.; Dhasarathan, M.; Thamodharan, G.; Baskar, M. Development of sodicity tolerant rice varieties through marker assisted backcross breeding. Electron. J. Plant Breed. $2017,8,1013$. [CrossRef]

119. Shailani, A.; Joshi, R.; Singla-Pareek, S.L.; Pareek, A. Stacking for future: Pyramiding genes to improve drought and salinity tolerance in rice. Physiol. Plant. 2021, 172, 1352-1362. [CrossRef]

120. Muthu, V.; Abbai, R.; Nallathambi, J.; Rahman, H.; Ramasamy, S.; Kambale, R.; Thulasinathan, T.; Ayyenar, B.; Muthurajan, R. Pyramiding QTLs controlling tolerance against drought, salinity, and submergence in rice through marker assisted breeding. PLoS ONE 2020, 15, e0227421. [CrossRef]

121. Luo, Y.; Ma, T.; Zhang, A.; Ong, K.H.; Li, Z.; Yang, J.; Yin, Z. Marker-assisted breeding of the rice restorer line Wanhui 6725 for disease resistance, submergence tolerance and aromatic fragrance. Rice 2016, 9, 66. [CrossRef]

122. Pradhan, S.K.; Nayak, D.K.; Mohanty, S.; Behera, L.; Barik, S.R. Pyramiding of three bacterial blight resistance genes for broad-spectrum resistance in deepwater rice variety, Jalmagna. Rice 2015, 8, 19. [CrossRef] [PubMed]

123. Bhatnagar-Mathur, P.; Vadez, V.; Sharma, K.K. Transgenic approaches for abiotic stress tolerance in plants: Retrospect and prospects. Plant Cell Rep. 2008, 27, 411-424. [CrossRef] [PubMed]

124. Liao, Y.-D.; Lin, K.-H.; Chen, C.-C.; Chiang, C.-M. Oryza sativa protein phosphatase 1a (OsPP1a) involved in salt stress tolerance in transgenic rice. Mol. Breed. 2016, 36, 22. [CrossRef] 
125. Amin, U.S.M.; Biswas, S.; Elias, S.M.; Razzaque, S.; Haque, T.; Malo, R.; Seraj, Z.I. Enhanced Salt Tolerance Conferred by the Complete $2.3 \mathrm{~kb}$ cDNA of the Rice Vacuolar Na${ }^{+} / \mathrm{H}^{+}$Antiporter Gene Compared to $1.9 \mathrm{~kb}$ Coding Region with $5^{\prime}$ UTR in Transgenic Lines of Rice. Front. Plant Sci. 2016, 7, 14. [CrossRef] [PubMed]

126. Chen, M.; Chen, Q.-J.; Niu, X.-G.; Zhang, R.; Lin, H.-Q.; Xu, C.-Y.; Wang, X.-C.; Wang, G.-Y.; Chen, J. Expression of OsNHX1 gene in maize confers salt tolerance and promotes plant growth in the field. Plant Soil Environ. 2008, 53, 490-498. [CrossRef]

127. Wang, W.-S.; Zhao, X.-Q.; Li, M.; Huang, L.-Y.; Xu, J.-L.; Zhang, F.; Cui, Y.-R.; Fu, B.-Y.; Li, Z.-K. Complex molecular mechanisms underlying seedling salt tolerance in rice revealed by comparative transcriptome and metabolomic profiling. J. Exp. Bot. 2016, 67, 405-419. [CrossRef]

128. Li, M.; Guo, L.; Guo, C.; Wang, L.; Chen, L. Over-expression of a DUF1644 protein gene, SIDP361, enhances tolerance to salt stress in transgenic rice. J. Plant Biol. 2016, 59, 62-73. [CrossRef]

129. Sahoo, R.K.; Ansari, M.W.; Tuteja, R.; Tuteja, N. OsSUV3 transgenic rice maintains higher endogenous levels of plant hormones that mitigates adverse effects of salinity and sustains crop productivity. Rice 2014, 7, 17. [CrossRef]

130. Nath, M.; Yadav, S.; Kumar Sahoo, R.; Passricha, N.; Tuteja, R.; Tuteja, N. PDH45 transgenic rice maintain cell viability through lower accumulation of $\mathrm{Na}+$, ROS and calcium homeostasis in roots under salinity stress. J. Plant Physiol. 2016, 191, 1-11. [CrossRef]

131. Das, P.; Mishra, M.; Lakra, N.; Singla-Pareek, S.L.; Pareek, A. Mutation Breeding: A Powerful Approach for Obtaining Abiotic Stress Tolerant Crops and Upgrading Food Security for Human Nutrition. Mutagenesis: Exploring Novel Genes and Pathways; Wageningen Academic Publisher: Wageningen, The Netherlands, 2014.

132. Hoang, T.; Tran, T.; Nguyen, T.; Williams, B.; Wurm, P.; Bellairs, S.; Mundree, S. Improvement of Salinity Stress Tolerance in Rice: Challenges and Opportunities. Agronomy 2016, 6, 54. [CrossRef]

133. Pental, D. When scientists turn against science: Exceptionally flawed analysis of plant breeding technologies. Curr. Sci. 2019, 117, 932-939. [CrossRef]

134. Pythoud, F. The Cartagena protocol and GMOs. Nat. Biotechnol. 2004, 22, 1347-1348. [CrossRef]

135. Fraiture, M.-A.; Roosens, N.H.C.; Taverniers, I.; De Loose, M.; Deforce, D.; Herman, P. Biotech rice: Current developments and future detection challenges in food and feed chain. Trends Food Sci. Technol. 2016, 52, 66-79. [CrossRef]

136. Moin, M.; Bakshi, A.; Saha, A.; Dutta, M.; Kirti, P.B. Gain-of-function mutagenesis approaches in rice for functional genomics and improvement of crop productivity. Brief. Funct. Genom. 2017, 16, 238-247. [CrossRef]

137. Oladosu, Y.; Rafii, M.Y.; Abdullah, N.; Hussin, G.; Ramli, A.; Rahim, H.A.; Miah, G.; Usman, M. Principle and application of plant mutagenesis in crop improvement: A review. Biotechnol. Biotechnol. Equip. 2016, 30, 1-16. [CrossRef]

138. Da Luz, V.K.; da Silveira, S.F.; da Fonseca, G.M.; Groli, E.L.; Figueiredo, R.G.; Baretta, D.; Kopp, M.M.; de Magalhães Junior, A.M.; da Maia, L.C.; de Oliveira, A.C. Identification of variability for agronomically important traits in rice mutant families. Bragantia 2016, 75, 41-50. [CrossRef]

139. Serrat, X.; Esteban, R.; Guibourt, N.; Moysset, L.; Nogués, S.; Lalanne, E. EMS mutagenesis in mature seed-derived rice calli as a new method for rapidly obtaining TILLING mutant populations. Plant Methods 2014, 10, 5. [CrossRef]

140. Parry, M.A.J.; Madgwick, P.J.; Bayon, C.; Tearall, K.; Hernandez-Lopez, A.; Baudo, M.; Rakszegi, M.; Hamada, W.; Al-Yassin, A.; Ouabbou, H.; et al. Mutation discovery for crop improvement. J. Exp. Bot. 2009, 60, 2817-2825. [CrossRef]

141. Wu, J.-L.; Wu, C.; Lei, C.; Baraoidan, M.; Bordeos, A.; Madamba, M.R.S.; Ramos-Pamplona, M.; Mauleon, R.; Portugal, A.; Ulat, V.J.; et al. Chemical- and Irradiation-induced Mutants of Indica Rice IR64 for Forward and Reverse Genetics. Plant Mol. Biol. 2005, 59, 85-97. [CrossRef]

142. Kharkwal, M.C.; Shu, Q.Y. The role of induced mutations in world food security. In Induced Plant Mutations in the Genomics Era; FAO: Rome, Italy, 2009; pp. 33-38.

143. Ahloowalia, B.S.; Maluszynski, M. Induced mutations in plant breeding. Euphytica 2001, 118, 167-173. [CrossRef]

144. Ahloowalia, B.S.; Maluszynski, M.; Nichterlein, K. Global impact of mutation-derived varieties. Euphytica 2004, 135, 187-204. [CrossRef]

145. Wang, W.; Vinocur, B.; Altman, A. Plant responses to drought, salinity and extreme temperatures: Towards genetic engineering for stress tolerance. Planta 2003, 218, 1-14. [CrossRef]

146. Hayashi, Y.; Takehisa, H.; Kazama, Y.; Ichida, H.; Ryuto, H.; Fukunishi, N.; Abe, T.; Kamba, C.; Sato, T. Effects of ion beam irradiation on mutation induction in rice. In Proceedings of the 18th International Conference on Cyclotrons and Their Applications (CYCLOTRONS 2007), Messina, Italy, 1-5 October 2007; pp. 237-239.

147. Nakhoda, B.; Leung, H.; Mendioro, M.S.; Mohammadi-nejad, G.; Ismail, A.M. Isolation, characterization, and field evaluation of rice (Oryza sativa L., Var. IR64) mutants with altered responses to salt stress. Field Crop. Res. 2012, 127, 191-202. [CrossRef]

148. Sathish, P.; Gamborg, O.L.; Nabors, M.W. Establishment of stable NaCl-resistant rice plant lines from anther culture: Distribution pattern of $\mathrm{K}+/ \mathrm{Na}+$ in callus and plant cells. Theor. Appl. Genet. 1997, 95, 1203-1209. [CrossRef]

149. Lin, K.-C.; Jwo, W.-S.; Chandrika, N.N.P.; Wu, T.-M.; Lai, M.-H.; Wang, C.-S.; Hong, C.-Y. A rice mutant defective in antioxidantdefense system and sodium homeostasis possesses increased sensitivity to salt stress. Biol. Plant. 2016, 60, 86-94. [CrossRef]

150. Novak, F.J.; Brunner, H. Plant breeding: Induced mutation technology for crop improvement. IAEA Bull. 1992, 4, 25-33.

151. Song, J.Y.; Kim, D.S.; Lee, M.C.; Lee, K.J.; Kim, J.B.; Kim, S.H.; Ha, B.K.; Yun, S.J.; Kang, S.Y. Physiological characterization of gamma-ray induced salt tolerant rice mutants. Aust. J. Crop Sci. 2012, 6, 421-429. 
152. Das, P.; Nutan, K.K.; Singla-Pareek, S.L.; Pareek, A. Understanding salinity responses and adopting 'omics-based' approaches to generate salinity tolerant cultivars of rice. Front. Plant Sci. 2015, 6, 712. [CrossRef]

153. Jaiswal, S.; Gautam, R.K.; Singh, R.K.; Krishnamurthy, S.L.; Ali, S.; Sakthivel, K.; Iquebal, M.A.; Rai, A.; Kumar, D. Harmonizing technological advances in phenomics and genomics for enhanced salt tolerance in rice from a practical perspective. Rice 2019, 12, 89. [CrossRef]

154. Huang, L.; Wu, D.; Zhang, G. Advances in studies on ion transporters involved in salt tolerance and breeding crop cultivars with high salt tolerance. J. Zhejiang Univ. B 2020, 21, 426-441. [CrossRef]

155. Kamburova, V.S.; Nikitina, E.V.; Shermatov, S.E.; Buriev, Z.T.; Kumpatla, S.P.; Emani, C.; Abdurakhmonov, I.Y. Genome Editing in Plants: An Overview of Tools and Applications. Int. J. Agron. 2017, 2017, 7315351. [CrossRef]

156. Yin, K.; Gao, C.; Qiu, J.-L. Progress and prospects in plant genome editing. Nat. Plants 2017, 3, 17107. [CrossRef] [PubMed]

157. Zischewski, J.; Fischer, R.; Bortesi, L. Detection of on-target and off-target mutations generated by CRISPR/Cas9 and other sequence-specific nucleases. Biotechnol. Adv. 2017, 35, 95-104. [CrossRef] [PubMed]

158. Geng, Y.; Deng, Z.; Sun, Y. An insight into the protospacer adjacent motif of Streptococcus pyogenes Cas9 with artificially stimulated RNA-guided-Cas9 DNA cleavage flexibility. RSC Adv. 2016, 6, 33514-33522. [CrossRef]

159. Fiaz, S.; Ahmad, S.; Noor, M.; Wang, X.; Younas, A.; Riaz, A.; Riaz, A.; Ali, F. Applications of the CRISPR/Cas9 System for Rice Grain Quality Improvement: Perspectives and Opportunities. Int. J. Mol. Sci. 2019, 20, 888. [CrossRef]

160. Endo, A.; Masafumi, M.; Kaya, H.; Toki, S. Efficient targeted mutagenesis of rice and tobacco genomes using Cpf1 from Francisella novicida. Sci. Rep. 2016, 6, 38169. [CrossRef] [PubMed]

161. Zetsche, B.; Gootenberg, J.S.; Abudayyeh, O.O.; Slaymaker, I.M.; Makarova, K.S.; Essletzbichler, P.; Volz, S.E.; Joung, J.; van der Oost, J.; Regev, A.; et al. Cpf1 Is a Single RNA-Guided Endonuclease of a Class 2 CRISPR-Cas System. Cell 2015, 163, 759-771. [CrossRef]

162. Pang, Y.; Chen, K.; Wang, X.; Wang, W.; Xu, J.; Ali, J.; Li, Z.; Roy, S.J. Simultaneous Improvement and Genetic Dissection of Salt Tolerance of Rice (Oryza sativa L.) by Designed QTL Pyramiding. Front. Plant Sci. 2017, 8, 1-11. [CrossRef]

163. Nishida, K.; Arazoe, T.; Yachie, N.; Banno, S.; Kakimoto, M.; Tabata, M.; Mochizuki, M.; Miyabe, A.; Araki, M.; Hara, K.Y.; et al. Targeted nucleotide editing using hybrid prokaryotic and vertebrate adaptive immune systems. Science 2016, 353 , aaf8729. [CrossRef]

164. Marcos, M.; Sharifi, H.; Grattan, S.R.; Linquist, B.A. Spatio-temporal salinity dynamics and yield response of rice in water-seeded rice fields. Agric. Water Manag. 2018, 195, 37-46. [CrossRef]

165. Zong, Y.; Wang, Y.; Li, C.; Zhang, R.; Chen, K.; Ran, Y.; Qiu, J.-L.; Wang, D.; Gao, C. Precise base editing in rice, wheat and maize with a Cas9-cytidine deaminase fusion. Nat. Biotechnol. 2017, 35, 438-440. [CrossRef] [PubMed]

166. Huang, Q.-N.; Shi, Y.-F.; Zhang, X.-B.; Song, L.-X.; Feng, B.-H.; Wang, H.-M.; Xu, X.; Li, X.-H.; Guo, D.; Wu, J.-L. Single base substitution in OsCDC48 is responsible for premature senescence and death phenotype in rice. J. Integr. Plant Biol. 2016, 58, 12-28. [CrossRef] [PubMed]

167. Li, J.; Sun, Y.; Du, J.; Zhao, Y.; Xia, L. Generation of Targeted Point Mutations in Rice by a Modified CRISPR/Cas9 System. Mol. Plant 2017, 10, 526-529. [CrossRef] [PubMed]

168. Mishra, R.; Joshi, R.K.; Zhao, K. Genome Editing in Rice: Recent Advances, Challenges, and Future Implications. Front. Plant Sci. 2018, 9, 1361. [CrossRef] [PubMed]

169. Tan Khang, D. Potential application and current achievements of CRISPR/Cas in rice. Ann. Biotechnol. 2018, 1, 1003. [CrossRef]

170. Zhang, H.; Zhang, J.; Wei, P.; Zhang, B.; Gou, F.; Feng, Z.; Mao, Y.; Yang, L.; Zhang, H.; Xu, N.; et al. The CRISPR/Cas9 system produces specific and homozygous targeted gene editing in rice in one generation. Plant Biotechnol. J. 2014, 12, 797-807. [CrossRef]

171. Sun, Y.; Zhang, X.; Wu, C.; He, Y.; Ma, Y.; Hou, H.; Guo, X.; Du, W.; Zhao, Y.; Xia, L. Engineering Herbicide-Resistant Rice Plants through CRISPR/Cas9-Mediated Homologous Recombination of Acetolactate Synthase. Mol. Plant 2016, 9, 628-631. [CrossRef] [PubMed]

172. Zhou, H.; He, M.; Li, J.; Chen, L.; Huang, Z.; Zheng, S.; Zhu, L.; Ni, E.; Jiang, D.; Zhao, B.; et al. Development of Commercial Thermo-sensitive Genic Male Sterile Rice Accelerates Hybrid Rice Breeding Using the CRISPR/Cas9-mediated TMS5 Editing System. Sci. Rep. 2016, 6, 37395. [CrossRef] [PubMed]

173. Nieves-Cordones, M.; Mohamed, S.; Tanoi, K.; Kobayashi, N.I.; Takagi, K.; Vernet, A.; Guiderdoni, E.; Périn, C.; Sentenac, H.; Véry, A. Production of low-Cs + rice plants by inactivation of the $\mathrm{K}+\operatorname{transporter}$ Os HAK 1 with the CRISPR-Cas system. Plant J. 2017, 92, 43-56. [CrossRef]

174. Shao, G.; Xie, L.; Jiao, G.; Wei, X.; Sheng, Z.; Tang, S.; Hu, P. CRISPR/CAS9-mediated editing of the fragrant gene Badh2 in rice. Chin. J. Rice Sci. 2017, 3, 216-222.

175. Zhang, A.; Liu, Y.; Wang, F.; Li, T.; Chen, Z.; Kong, D.; Bi, J.; Zhang, F.; Luo, X.; Wang, J.; et al. Enhanced rice salinity tolerance via CRISPR/Cas9-targeted mutagenesis of the OsRR22 gene. Mol. Breed. 2019, 39, 47. [CrossRef]

176. Zeng, Y.; Wen, J.; Zhao, W.; Wang, Q.; Huang, W. Rational Improvement of Rice Yield and Cold Tolerance by Editing the Three Genes OsPIN5b, GS3, and OsMYB30 With the CRISPR-Cas9 System. Front. Plant Sci. 2020, 10, 1663. [CrossRef]

177. Shan, Q.; Wang, Y.; Li, J.; Zhang, Y.; Chen, K.; Liang, Z.; Zhang, K.; Liu, J.; Xi, J.J.; Qiu, J.-L.; et al. Targeted genome modification of crop plants using a CRISPR-Cas system. Nat. Biotechnol. 2013, 31, 686-688. [CrossRef]

178. Tak, Y.G.; Farnham, P.J. Making sense of GWAS: Using epigenomics and genome engineering to understand the functional relevance of SNPs in non-coding regions of the human genome. Epigenet. Chromatin 2015, 8, 57. [CrossRef] [PubMed] 
179. Druka, A.; Potokina, E.; Luo, Z.; Jiang, N.; Chen, X.; Kearsey, M.; Waugh, R. Expression quantitative trait loci analysis in plants. Plant Biotechnol. J. 2010, 8, 10-27. [CrossRef] [PubMed]

180. Fernando, L.H. The performance of salt resistant paddy, Pokkali in Ceylon. Trop. Agric. 1949, 105, 124-126.

181. Qin, H.; Li, Y.; Huang, R. Advances and Challenges in the Breeding of Salt-Tolerant Rice. Int. J. Mol. Sci. 2020, 21, 8385. [CrossRef] [PubMed]

182. Ahmed, A.U.; Hernandez, R.; Naher, F. Adoption of Stress-Tolerant Rice Varieties in Bangladesh. In Technological and Institutional Innovations for Marginalized Smallholders in Agricultural Development; Springer International Publishing: Cham, Switzerland, 2016; pp. 241-255.

183. Sun, M.F.; Yan, G.H.; Wang, A.M.; Zhu, G.Y.; Tang, H.S.; He, C.X.; Ren, Z.L.; Liu, K.; Zhang, G.Y.; Shi, W.; et al. Research progress on the breeding of salt-tolerant rice varieties. Barley Cereal. Sci. 2017, 34, 1-9.

184. Das, G.; Rao, G.J.N.; Varier, M.; Prakash, A.; Prasad, D. Improved Tapaswini having four BB resistance genes pyramided with six genes/QTLs, resistance/tolerance to biotic and abiotic stresses in rice. Sci. Rep. 2018, 8, 2413. [CrossRef]

185. Thanasilungura, K.; Kranto, S.; Monkham, T.; Chankaew, S.; Sanitchon, J. Improvement of a RD6 Rice Variety for Blast Resistance and Salt Tolerance through Marker-Assisted Backcrossing. Agronomy 2020, 10, 1118. [CrossRef]

186. Ho, V.T.; Thomson, M.J.; Ismail, A.M. Development of salt tolerant IR64 near isogenic lines through marker-assisted breeding. J. Crop Sci. Biotechnol. 2016, 19, 373-381. [CrossRef]

187. Yadav, A.K.; Kumar, A.; Grover, N.; Ellur, R.K.; Krishnan, S.G.; Bollinedi, H.; Bhowmick, P.K.; Vinod, K.K.; Nagarajan, M.; Krishnamurthy, S.L.; et al. Marker aided introgression of 'Saltol', a major QTL for seedling stage salinity tolerance into an elite Basmati rice variety 'Pusa Basmati 1509'. Sci. Rep. 2020, 10, 13877. [CrossRef]

188. Singh, V.K.; Singh, B.D.; Kumar, A.; Maurya, S.; Krishnan, S.G.; Vinod, K.K.; Singh, M.P.; Ellur, R.K.; Bhowmick, P.K.; Singh, A.K. Marker-Assisted Introgression of Saltol QTL Enhances Seedling Stage Salt Tolerance in the Rice Variety "Pusa Basmati 1". Int. J. Genom. 2018, 2018, 1-12. [CrossRef] [PubMed]

189. Krishnamurthy, S.L.; Pundir, P.; Warraich, A.S.; Rathor, S.; Lokeshkumar, B.M.; Singh, N.K.; Sharma, P.C. Introgressed Saltol QTL Lines Improves the Salinity Tolerance in Rice at Seedling Stage. Front. Plant Sci. 2020, 11, 833. [CrossRef]

190. Nair, M.M.; Shylaraj, K.S. Introgression of dual abiotic stress tolerance QTLs (Saltol QTL and Sub1 gene) into Rice (Oryza sativa L.) variety Aiswarya through marker assisted backcross breeding. Physiol. Mol. Biol. Plants 2021, 27, 497-514. [CrossRef]

191. Valarmathi, M.; Sasikala, R.; Rahman, H.; Jagadeeshselvam, N.; Kambale, R.; Raveendran, M. Development of salinity tolerant version of a popular rice variety improved white ponni through marker assisted back cross breeding. Plant Physiol. Rep. 2019, 24, 262-271. [CrossRef]

192. Mukherjee, R.; Mukherjee, A.; Bandyopadhyay, S.; Mukherjee, S.; Sengupta, S.; Ray, S.; Majumder, A.L. Selective manipulation of the inositol metabolic pathway for induction of salt-tolerance in indica rice variety. Sci. Rep. 2019, 9, 5358. [CrossRef]

193. Tan, L.W.; Rahman, Z.A.; Goh, H.H.; Hwang, D.J.; Ismail, I.; Zainal, Z. Production of transgenic rice (indica cv. MR219) overexpressing ABP57 gene through Agrobacterium-mediated transformation. Sains Malays 2017, 46, 703-711. [CrossRef] 